Emmanuel KASONGO YAKUSU, $1,2,3$

Dominique LOUPPE 4,5

Franck K. MONTHE ${ }^{6,7}$

Olivier J. HARDY ${ }^{6}$

Félicien Bola MBele LOKANDA ${ }^{8}$

Wannes HUBAU 1,2

Jan VAN den BULCKE

Joris VAN ACKER ${ }^{1}$

Hans BEECKMAN ${ }^{2}$

Nils BOURLAND 9,10

Translation checked by llona BosSANYI ${ }^{4,5,1}$

Article previously published in French in the journal Bois et Forêts des Tropiques, No 339, January-March 2019:

Kasongo Yakusu E., Louppe D., Monthe K. F., Hardy O.

J., Bola Mbele Lokanda F., Hubau W., Van den Bulcke J.,

Van Acker J., Beeckman H., Bourland N., 2019. Enjeux et amélioration de la gestion des espèces du genre Entandrophragma, arbres africains devenus vulnérables. Bois et Forêts des Tropiques, $339: 75-94$. Doi : https://doi. org/10.19182/bft2019.339.a31717

${ }^{1}$ Ghent University

Department of Environment

Laboratory of Wood Technology

UGent-Woodlab

Coupure Links 653

9000 Gand

Belgium

${ }^{2}$ Royal Museum for Central Africa

Service of Wood Biology

Leuvensesteenweg, 13

3080 Tervuren

Belgium

${ }^{3}$ Université de Kisangani

Faculty of Natural Renewable Resources Management

B.P. 2012, avenue Kitima, 3

Kisangani

Democratic Republic of the Congo

${ }^{4}$ CIRAD

Forests \& Societies

34398 Montpellie

France

Forests \& Societies

Univ Montpellier, CIRAD

Montpellier

France

Université libre de Bruxelles

Faculty of Sciences

Biological Evolution and Ecology

CP 160/12, F. D. Roosevelt Avenue, 50

1050 Brussels

Belgium

Nature+ asbl / TERRA Forest Is Life,

Gembloux Agro-Bio Tech, Université de Liège,

Passage des déportés 2 .

5030 Gembloux,

Belgium

${ }^{8}$ University of Kisangani

Faculty of Sciences

BP 2012, Avenue Kitima, 3

Kisangani

Democratic Republic of the Congo

${ }^{9}$ Center for International Forestry Research

Situ Gede. Bogor Barat 16115

Indonesia

${ }^{10}$ Resources and Synergies Development Pte Ltd.

Hong Leong Building

Singapore 04858

Singapore

${ }^{11}$ Cirad, Bois et Forêts des Tropiques

34000 Montpellie

France

Auteur correspondant

Corresponding author:

Emmanuel Kasongo Yakusu

Emmanuel.KasongoYakusu@UGent.be

emmakasongo1@yahoo.fr

\section{Improved management of species of the African Entandrophragma genus, now listed as vulnerable}

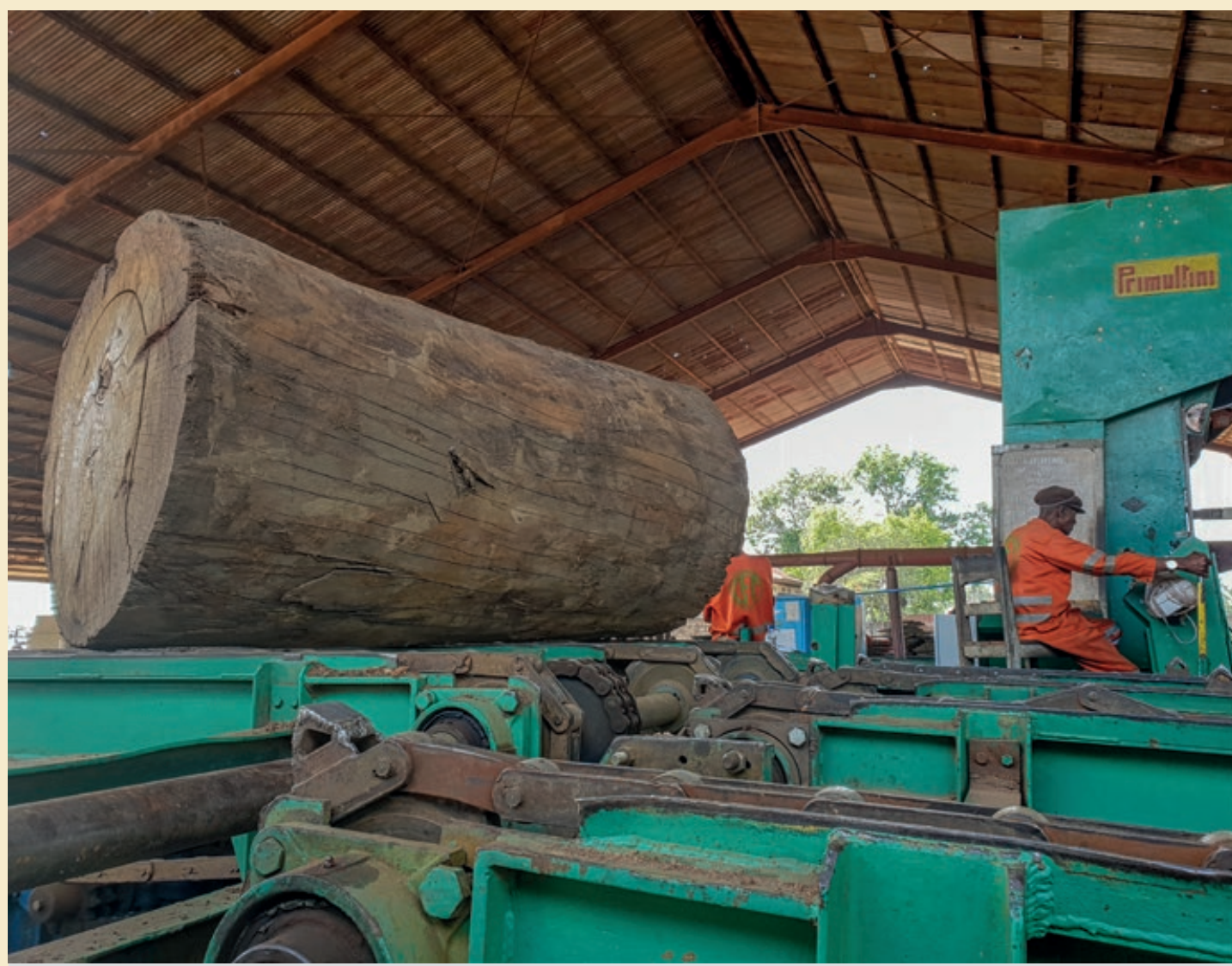

Photo 1.

Entandrophragma cylindricum log in a processing plant (CFT) in Kisangani (DRC).

Photo N. Bourland.

Doi : 10.19182/bft2021.349.a36791 - Droit d'auteur (c) 2018, Bois et Forêts des Tropiques - (C) Cirad - Date de soumission : 12 février 2018 ; date d'acceptation : 30 octobre 2018 ; date de publication version française : 15 janvier 2019 ; date de publication version anglaise : $1^{\text {er }}$ septembre 2021 .

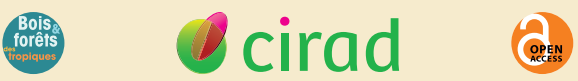

(c) (1)
Citer l'article / To cite the article

Kasongo Yakusu E., Louppe D., Monthe K. F., Hardy O. J., Bola Mbele Lokada F., Hubau W., Van den Bulcke J., Van Acker J., Beeckman H., Bourland N., 2021. Improved management of species of the African Entandrophragma genus, now listed as vulnerable. Bois et Forêts des Tropiques, 349 : 65-84. Doi : https://doi.org/10.19182/bft2021.349.a36791 


\section{RÉSUMÉ}

Enjeux et amélioration de la gestion des espèces du genre Entandrophragma, arbres africains devenus vulnérables

Par la qualité de leur bois et leurs nombreux usages traditionnels, les espèces du genre Entandrophragma font l'objet d'une intense exploitation, susceptible de compromettre leur pérennité en l'absence de gestion durable. La présente étude dresse un état de la situation de cinq espèces commerciales principales de ce genre : Entandrophragma angolense, E. congoense (souvent assimilée par erreur à E. angolense), E. candollei, E. cylindricum et $E$. utile. Elle propose des pistes de recherche pour améliorer les stratégies de gestion durable au sein de ce genre. L'étude est principalement basée sur les données scientifiques (publications), économiques (statistiques de production et d'exportation) et juridiques (lois et réglementations), mais aussi sur les plans d'aménagement et les rapports d'inventaire. Les connaissances sur leur gestion sont encore fragmentaires alors qu'elles sont considérées comme vulnérables dans la liste rouge de I'UICN. La forte exploitation industrielle et artisanale de ces espèces ne s'effectue pas toujours dans le respect d'un plan d'aménagement validé, ni de la durée minimum des rotations qui permettraient l'un et l'autre un taux de reconstitution pérennisant cette ressource. Leur gestion durable exige notamment le développement et le respect de mesures d'aménagement pour rendre leur exploitation renouvelable à long terme. Cette exploitation doit s'appuyer sur une gestion adéquate des peuplements naturels et sur le reboisement ainsi que sur des mesures de conservation. Les recherches à développer doivent intéresser leur vitesse de croissance face aux évolutions climatiques, l'évaluation de leurs stocks (production, biomasse, carbone), l'actualisation de leur distribution spatiale, l'amélioration de leur régénération naturelle, les processus de leur reproduction, leurs propriétés anatomiques et technologiques, autant de pistes pertinentes pour garantir la pérennité des espèces exploitables du genre Entandrophragma.

\section{Mots-clés : Entandrophragma,}

aménagement forestier, exploitation forestière, bois, économie, forêt dense humide, gestion durable, reboisement, Afrique.

\section{ABSTRACT}

\section{Improved management of species of the African Entandrophragma genus, now listed as vulnerable}

Because of the quality of their wood and their many traditional uses, species of the Entandrophragma genus are being intensively logged, and this is likely to compromise their survival unless sustainable management is introduced. This study reviews the current status of the five main commercial Entandrophragma species: Entandrophragma angolense, E. congolense (often confused with $E$. angolense), E. candollei, E. cylindricum and E. utile. We suggest directions for research to improve sustainable management strategies for this genus. The study draws mainly on published scientific data, economic data (production and export statistics) and on relevant laws and regulations, but also on existing management plans and inventory reports. Although these species are reported as vulnerable on the IUCN Red List, knowledge on their management is still patchy. Industrial and artisanal logging is intensive and does not always follow a validated management plan or abide by the minimum rotation period, both of which would help to ensure the renewal of these resources. Managing them to ensure that logging is sustainable in the long term requires management measures to be developed and complied with. Sustainable use has to be based on appropriate management of natural stands and on reforestation and conservation measures. Research studies to be developed should encompass the growth rates of the species in the light of the changing climate, assessments of stocks (timber, biomass and carbon), updates of their spatial distribution, improvements to natural regeneration, reproduction processes and the anatomical and technical properties of each species. All these research topics are necessary to ensure the permanence of these Entandrophragma species.

Keywords: Entandrophragma, forestry, logging, wood, economy, dense humid forest, sustainable management, reforestation, Africa.

\section{Retos y mejoras para la gestión de las especies del género Entandrophragma, árboles africanos que han pasado a ser vulnerables}

Por la calidad de su madera y sus numerosos usos tradicionales, las especies del género Entandrophragma son objeto de una intensa explotación, que puede comprometer su durabilidad sin una gestión sostenible. Este estudio describe la situación de las cinco especies comerciales principales de este género: Entandrophragma angolense, E. congoense (a menudo asimilada por error a $E$. angolense), E. candollei, E. cylindricum y E. utile. $Y$ propone líneas de investigación para mejorar las estrategias de gestión sostenible aplicadas a este género. El estudio se basa principalmente en los datos científicos (publicaciones), económicos (estadísticas de producción y de exportación) y jurídicos (leyes y reglamentaciones), pero también en la ordenación forestal y los informes de los inventarios. Los conocimientos sobre la gestión de estas especies todavía son parciales, mientras que se consideran vulnerables en la lista roja de la UICN. La fuerte explotación industrial y artesanal de estas especies no se realiza siempre respetando un plan de ordenación validado, ni la duración mínima de las rotaciones que permitirían una tasa de repoblación que perpetuase este recurso. Su gestión sostenible exige principalmente el desarrollo y el respeto de medidas de ordenación para que la explotación sea renovable a largo plazo. Esta explotación debe basarse en una gestión adecuada de las poblaciones naturales y en la repoblación, así como en las medidas de conservación. Las investigaciones que se desarrollen deben tener en consideración la velocidad de crecimiento ante las evoluciones climáticas, la evaluación de los stocks (producción, biomasa, carbono), la actualización de la distribución espacial, la mejora de la regeneración natural, los procesos de reproducción, las propiedades anatómicas y tecnológicas, todas ellas pistas pertinentes para garantizar la perpetuidad de las especies explotables del género Entandrophragma.

Palabras clave: Entandrophragma, ordenación forestal, explotación forestal, leña, economía, bosque denso húmedo, gestión sostenible, repoblación, África. 


\section{Introduction}

Timber extraction is one of the direct causes of tropical deforestation (Geist et al., 2002; Gillet et al., 2016). However, Karsenty and Ongolo (2012) note that, apart from cases of very intensive timber extraction in South-East Asia and Latin America, logging in the humid tropics is generally selective and rarely leads directly to sufficient felling and damage to be considered as deforestation. In the Congo Basin, Doucet and Kouadio (2007) point out that the timber market is also highly selective and that, as a result, extraction is limited to the largest and finest trees of a few species of high market value. In this context, the extraction of high-quality stems of a small number of species can actually result in genetic skimming of these species (Nanson, 2004). This high risk of genetic erosion concerns many African tree species of economic interest, including Entandrophragma.

The genus Entandrophragma C. DC. includes, depending on sources, 10 to 12 tree species distributed exclusively in tropical Africa (Kasongo Yakusu et al., 2018). Within the Meliaceae family, this genus is the richest in precious species that have been logged for decades for industrial timber (Tailfer, 1989; Kasongo Yakusu et al., 2018; Lebacq et al., 1950) because of the excellent quality of their wood, which is suited to a variety of uses including cabinet making. Lescuyer et al. (2012) show that these species are also extracted by artisan loggers. The technological quality of the wood, and therefore its commercial value, varies from one species to another. Populations of Entandrophragma in dense humid forests include E. angolense (Welw.) C. DC. (trade name: white tiama), E. candollei Harms (kosipo), E. congolense (Pierre ex De Wild.) A. Chev. (black tiama), E. cylindricum (Dawe \& Sprague) Sprague (sapelli), and E. utile (Dawe \& Sprague) Sprague (sipo). They are distributed across a wide band north and south of the equator from the Atlantic coast through the Congo Basin to the western slope of the Kivu Ridge in the east (White, 1986; Kasongo Yakusu et al., 2018). These species provide some of the most valuable timber (Hall, 2008; IITO, 2017). In the Central African Republic (CAR), they account for more than $70 \%$ of the total volume of timber exported (Hall, 2008). They have been heavily exploited in West Africa: Côte d'Ivoire, for example, exported more than 3.7 million $\mathrm{m}^{3}$ of Entandrophragma logs and more than $400,000 \mathrm{~m}^{3}$ of sawn timber between 1970 and 1974. As a result, logging of these species has dried up in West Africa while gradually shifting to Central Africa (Bayol et al., 2012).

The five main Entandrophragma species extracted grow in evergreen and semi-deciduous dense humid forests (Meunier et al., 2015; Kasongo Yakusu et al., 2018) where they have been logged to such an extent that natural regeneration has not been able to restore populations to their initial states, all the more so as natural regeneration is sometimes defective in these species (Lemmens, 2008). This state of affairs is raising serious concerns about the conservation risks weighing on these species, which are now listed as "vulnerable" on the IUCN Red List (IUCN, 2012). Listing in this category is not intended to prohibit their extraction, but rather to draw the attention of forest managers (e.g. States and logging companies) to the need to create the necessary conditions to manage forest resources, and these species more specifically, for sustainability. The conservation status of Entandrophragma species will certainly evolve according to the conditions of their extraction and regeneration and their population dynamics. It is therefore advisable to draw up a status report on these species, taking into account not only their economic importance but also the legislation and regulations in force concerning resource management. Relevant information should therefore be collected on their growth dynamics, their environmental requirements and their economic value based on the anatomical and technological properties of their wood and on their social importance.

The aim of this review is to gather and analyze published knowledge on the most heavily exploited Entandrophragma species in Africa (sapelli, sipo, kosipo, black and white tiamas) in order to:

- characterize their growth and the quality of their wood;

- evaluate the scale of their extraction;

- describe their economic, industrial and commercial status;

- analyze the impact of legal and regulatory measures concerning forest development and management;

- discuss the relevance of their conservation status in the light of anthropogenic pressures on their populations; and - identify research themes aimed at good management of their populations in order to ensure that their extraction is sustainable.

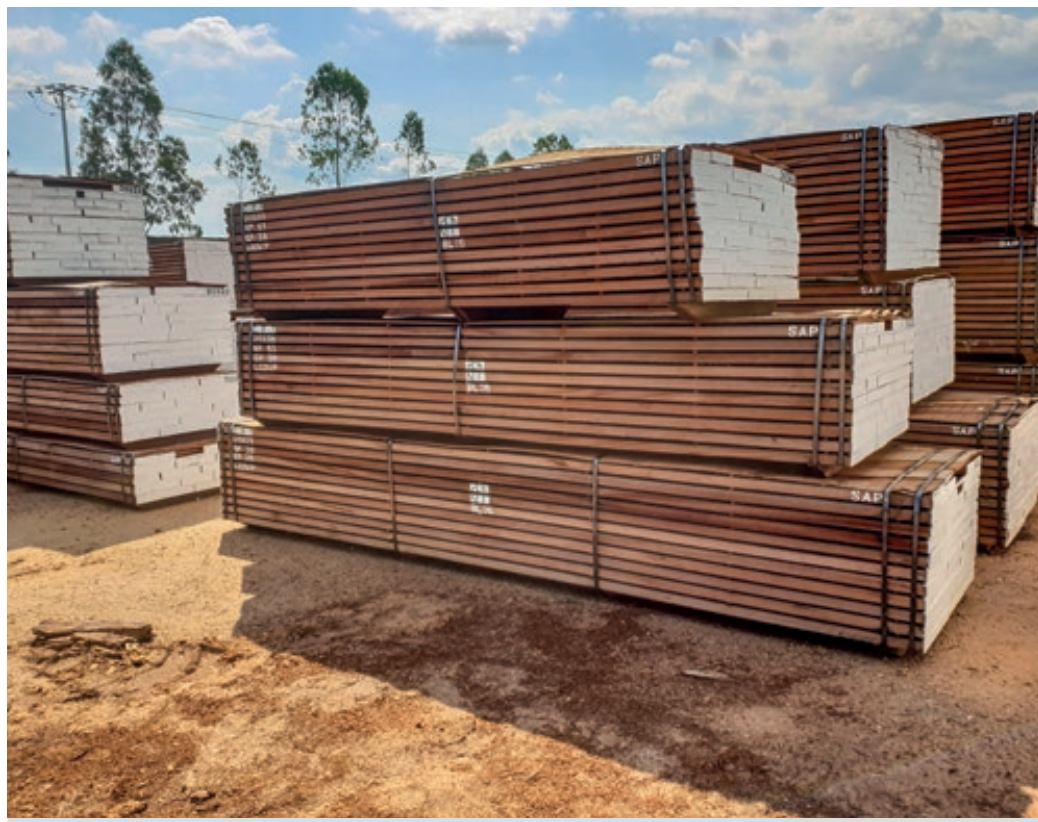

Photo 2.

Sawn timber of Entandrophragma cylindricum ready for export. Photo N. Bourland. 


\section{Growth dynamics}

\section{Tree-ring analysis and growth rates}

\section{Tree-ring analysis}

Distinct growth rings are marked by a sudden structural change at the boundaries between them, usually involving a change in fibre wall thickness and/or radial fibre diameter, whereas indistinct or absent growth rings are unclear and marked by more or less progressive structural changes at their ill-defined or non-visible boundaries (IAWA, 1989). Tree ring analysis makes it possible to measure a tree's past growth rate and its variations (e.g. due to climatic changes through analysis of the ring width/rainfall relationship) and

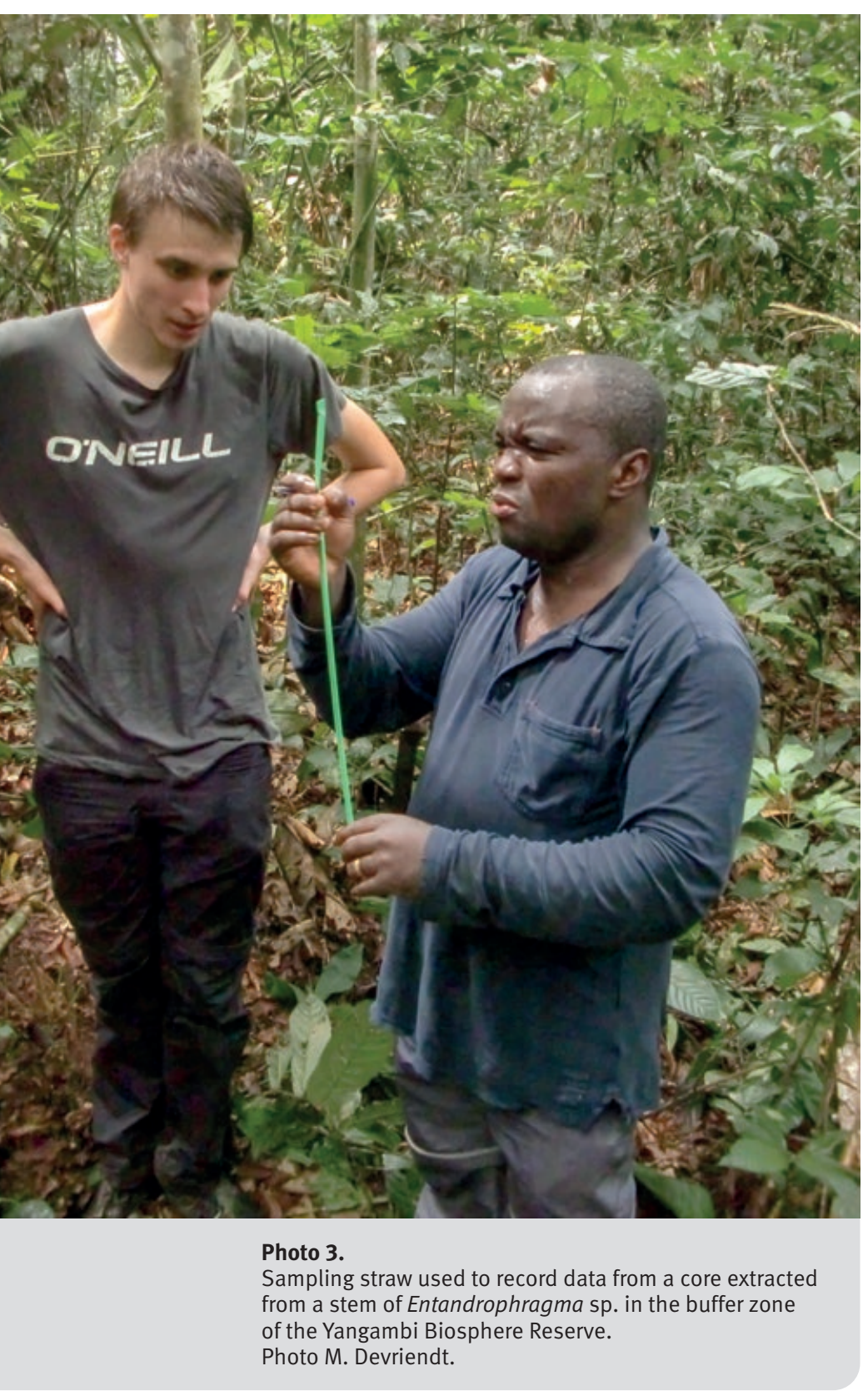

to estimate its age. The presence and legibility of rings thus allow dendrochronological analysis, provided that each ring can be associated with a given year and measured accurately (Fétéké et al., 2016). The first observations made on Entandrophragma, notably E. cylindricum and E. utile, show rings bordered by a thin continuous line and likely to be annual (Détienne and Mariaux, 1977; Porter et al., 2004). However, Banak et al. (2008) note that the ring boundaries of $E$. angolense, $E$. cylindricum and $E$. utile are sometimes indistinct or absent and those of $E$. candollei are generally indistinct or absent. Although reading the rings in species of the genus Entandrophragma can be difficult, doing so would bring a better understanding of their diametric growth rate, at least for some of the species.

The study of stable oxygen isotopes $(\delta 180)$ in the growth rings of tropical trees is another promising tool for high-resolution (annual) climate reconstructions. Because of the easily measurable and datable growth rings in $E$. utile, the presence of a strong common $\delta 180$ signal and its relationship with regional rainfall, Van der Sleen et al. (2015) argue that $\delta 180$ analysis of these rings is a promising tool for reconstructing climate variability over the past few centuries in Africa. This new research applied to other commercial Entandrophragma species would allow climate reconstructions from distinct growth rings.

\section{Growth rate}

According to Couralet et al. (2010), the growth rate of trees, and thus the formation of growth rings, depends mainly on climatic variations. The optimal seasons for diametric growth and ring formation in Entandrophragma in Côte d'Ivoire, Cameroon and CAR are the two rainy seasons. A brief cessation of diametric growth in some stems is observed during the short dry season in July-August, while the long dry season corresponds to a period of slow or no growth (Détienne et al., 1977; Fétéké et al., 2016). In general, the resumption of growth activity in Entandrophragma occurs during the first rainy month and is not modified by variations in the rainfall regime during the growing season from April to November (Détienne et al., 1977).

\section{Measuring increase in diameter}

In Central and West Africa, management rules for commercial species are based on the recovery rate of the number and standing volume of target species (Durrieu de Madron and Forni, 1997). The calculation of the recovery rate is based in particular on the rate of diametric growth (Fétéké et al., 2016). Tree-ring analysis and diameter measurements repeated over time (table I) have been carried out in Cameroon, Côte d'Ivoire, Ghana, CAR and the Republic of 
Table I.

Average annual diametric increase of Entandrophragma species.

Cam: Cameroun; CAR: Central African Republic; Cl: Côte d'Ivoire; RC: Republic of the Congo.

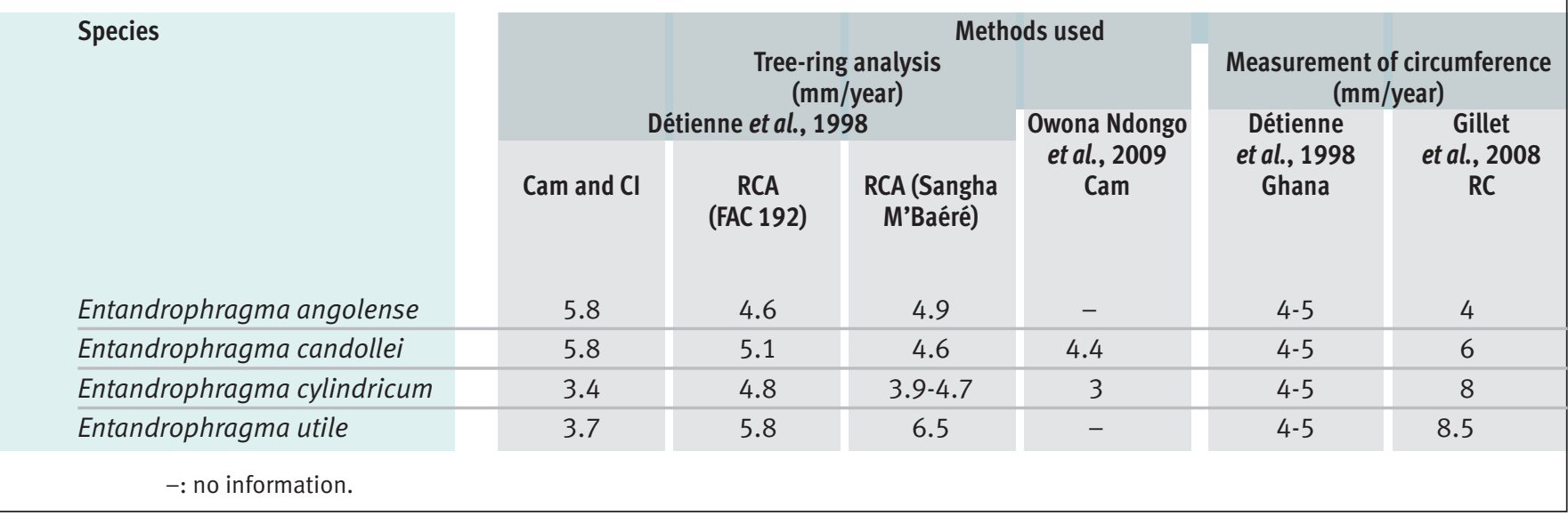

the Congo (Congo) to study the growth of certain commercial Entandrophragma species (Détienne and Mariaux, 1977; Adler, 1989; Détienne et al., 1998; Durrieu de Madron et al., 2000; Gillet et al., 2008; Owona Ndongo et al., 2009; Fétéké et al., 2015, 2016).

The increases observed with these two methods are comparable. For a given species, they give fairly precise ranges of diametric growth rates and make it possible to calculate the recovery rate between two rotations. In order to refine the knowledge of their growth in diameter, further research would be needed on the basis of larger numbers distributed over the entire range of Entandrophragma (Durrieu de Madron et al., 2000). As growth rates also strongly depend on the social hierarchy of a tree in relation to neighbouring stems (Gillet et al., 2008), the diametric growth of the tree should be measured in relation to its social status (dominated, co-dominant and dominant). According to Durrieu de Madron et al. (2000), the average annual diametric growth of $E$. cylindricum varies from 2.8 to $7.7 \mathrm{~mm} /$ year, but Gillet et al. (2008) showed that part of this variability can be explained by the social status of the tree. These authors thus determined that the average growth in diameter of a dominated tree was $5 \mathrm{~mm} /$ year, $8 \mathrm{~mm} /$ year for a co-dominant and $11 \mathrm{~mm} /$ year for a dominant tree. However, the growth rate also depends on other factors such as soil quality, inter-annual climate variability, especially rainfall, and the intensity and history of logging operations, which in particular modify competition between trees. As a result of all these factors, the growth of a sapelli (as well as other Entandrophragma species) can vary by as much as a factor of two depending on the year (Fétéké et al., 2016).

\section{Anatomical and technological properties}

The origin and growing conditions of a tree influence the physical and mechanical properties of its wood (Guibal et al., 2016). Applied anatomy helps to understand the properties of wood materials and to explain variations in the quality of wood and processed products (Louppe, 2015). Gérard (1999) therefore recommends that these properties, which make it possible to qualify wood according to its intended use, should be systematically studied and analyzed in order to optimize the use of African species and respond in a relevant way to the demands of industrialists and end users. Anatomy, through the identification of logs and processed wood, makes it possible to control the timber trade, and particularly illegal trade. It can therefore contribute to the sustainable management of certain tree species whose excessive extraction and trade can result in the disappearance of their habitat, or even their extinction (Louppe, 2015). This knowledge is necessary to justify priority measures to ensure that species threatened by intensive extraction, in this case Entandrophragma, are managed sustainably (e.g. orientation towards forestry and integration into a reforestation programme).

\section{Anatomical properties}

Anatomical descriptions of Entandrophragma wood according to IAWA standards have been made by several authors under PROTA (Louppe et al., 2008). These descriptions have been integrated into the InsideWood website (http://insidewood.lib.ncsu.edu). Anatomically, the wood of these species differs little except for a few distinctive features (Brazier and Franklin, 1961; Banak et al., 2008; 
Table II.

Distinctive anatomical features of the wood of Entandrophragma species (adapted from Banak et al., 2008).

Anatomical feature: totally distinctive (unique to the species concerned); moderately distinctive

(also observed in a species other than the species concerned) and marginally distinctive

(also observed in two species other than the species concerned).

\begin{abstract}
Species

Entandrophragma
angolense

Totally distinctive

12: solitary vessel outline angular; 107: Body ray cells procumbent with mostly 2 to 4 rows of upright and/or square marginal cells.
\end{abstract}

\section{Entandrophragma candollei}

phragma cylindricum
43: Mean tangential diameter of vessel lumina $\geq 200$ $\mu \mathrm{m}$; 84: Axial parenchyma unilateral paratracheal; 159: Silica bodies present in axial rays; 161 : Silica bodies in axial parenchyma cells.

\section{Moderately distinctive}

94: over eight cells per parenchyma strand.
1: Growth ring boundaries distinct; 98: Larger rays commonly 4 - to 10 - seriate; 115 : Rays per millimetre (4-12/mm); 136: Prismatic crystals present; 141: Prismatic crystals in non-chambered axial parenchyma cells; 142: Prismatic crystals in chambered axial parenchyma cells.

46: Vessels per square millimetre $(\leq 5$ vessels per square millimetre); 94: Over eight cells per parenchyma strand.
82: Axial parenchyma winged-aliform; 85: Axial parenchyma bands more than three cells wide; 86 : Axial parenchyma in narrow bands or lines up to three cells wide; 98: Larger rays commonly 4- to 10-seriate; 115: Rays per millimetre $(4-12 / \mathrm{mm})$.
25: Intervessel pits small (4-7 $\mu \mathrm{m}) ; 81$ : Axial parenchyma lozenge-aliform.
97: Ray width 1 to 3 cells; 104: All ray cells procumbent; 118: All rays storied; 131: Intercellular canals of traumatic origin; 137 : Prismatic crystals in upright and/or square ray cells.
1: Growth ring boundaries distinct; 82: Axial parenchyma winged-aliform; 85: Axial parenchyma bands more than three cells wide; 86 : Axial parenchyma in narrow bands or lines up to three cells wide; 98: Larger rays commonly 4- to 10-seriate; 115: Rays per millimetre $(4-12 / \mathrm{mm})$; 141: Prismatic crystals in non-chambered axial parenchyma cells; 142: Prismatic crystals in chambered axial parenchyma cells.

46: Vessels per square millimetre $(\leq 5$ vessels per square millimetre); 97: Ray width 1 to 3 cells; 104: All ray cells procumbent; 118: All rays storied; 131: Intercellular canals of traumatic origin; 137: Prismatic crystals in upright and /or square ray cells.
1: Growth ring boundaries distinct; 82: Axial parenchyma winged-aliform; 85: Axial parenchyma bands more than three cells wide; 86 : Axial parenchyma in narrow bands or lines up to three cells wide; 136: Prismatic crystals present; 141: Prismatic crystals in non-chambered axial parenchyma cells; 142 : Prismatic crystals in chambered axial parenchyma cells. table II). The anatomical identification key for the four main Entandrophragma species proposed by Brazier and Franklin (1961) was established from a small number of specimens (4-7 per species). It has therefore been completed (table II) thanks to the anatomical descriptions made by Banak et al. (2008).

Five features fully characterize $E$. candollei $(43,84$, 159, 160 and 161); two distinguish $E$. angolense (12 and $107)$ and $E$. cylindricum (25 and 81). Five moderately distinctive anatomical features $(97,104,118,131$ and 137) bring $E$. cylindricum and $E$. utile closer together, which are otherwise separated by two anatomical features (25 and 81); the marginally distinctive feature (98) is observed in $E$. cylindricum, and the (46) in E. utile. In addition, the wood of E. cylindricum often has a more pleasing colour and is more attractively patterned (Lemmens et al., 2008). The same moderately distinctive anatomical feature (94) is common to the wood of $E$. candollei and $E$. angolense. E. candollei differs from the other three species by the presence of silica in the rays, the axial parenchyma and in the fibres $(159,160$ and 161).

The wood anatomy of these species should be studied in greater depth to better distinguish the growth ring boundaries by analyzing the diameter of the vessels. Measuring the width of growth rings from the pith to the bark at different heights of the trunk would thus improve knowledge of the growth in diameter and height of Entandrophragma (Beeckman, 2016). 
Table III.

The main physical and mechanical features of commercial Entandrophragma species.

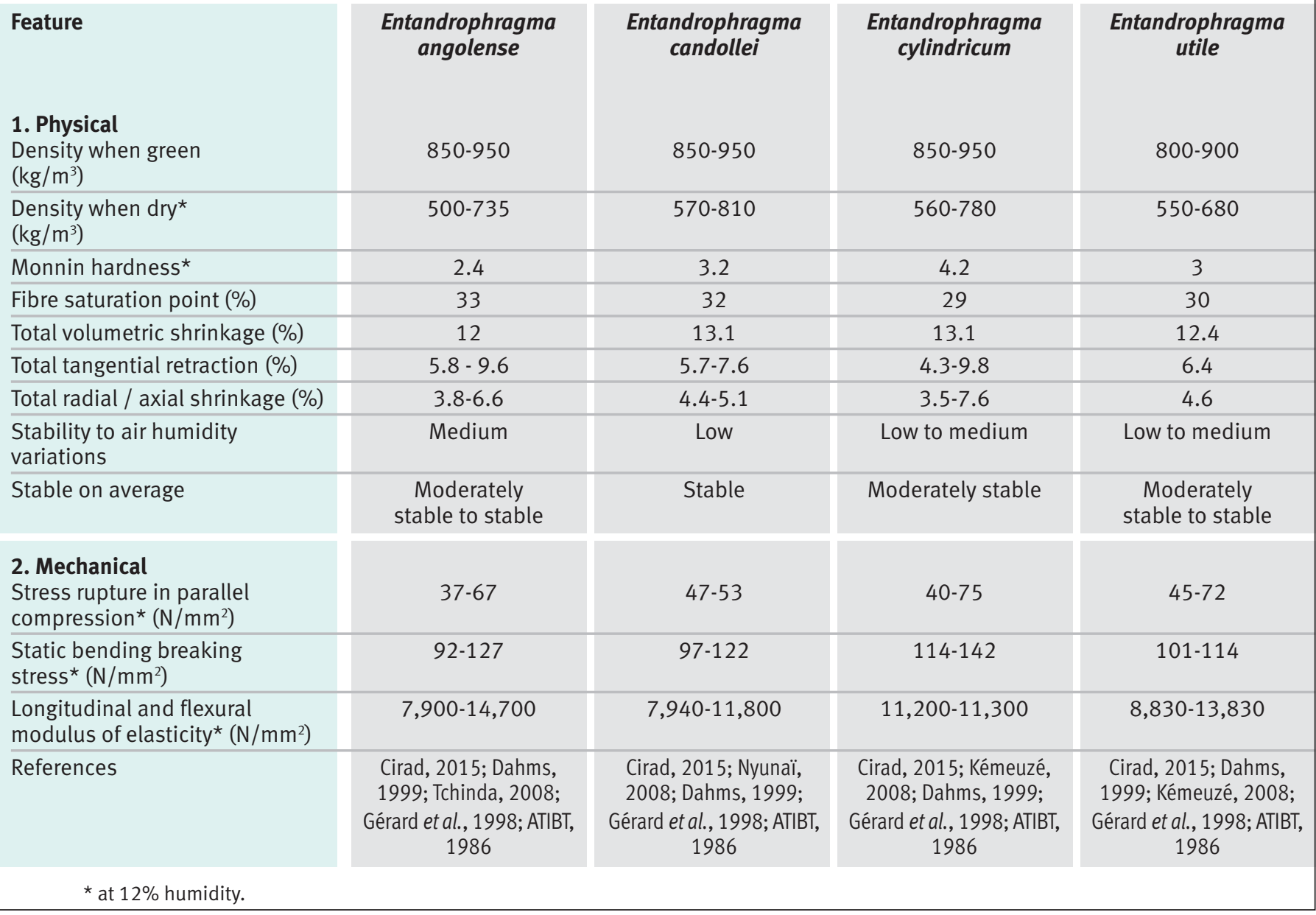

\section{Socio-economic value}

\section{Technological properties}

The timber properties of the main commercially extracted Entandrophragma species are well documented (ATIBT, 1986; Gérard et al., 1998; Dahms, 1999; Kémeuzé, 2008; Nyunaï, 2008; Tchinda, 2008; CIRAD, 2015; Gérard et al., 2016). They seem to vary greatly from one species to another as well as within the same species. The main physical and mechanical characteristics (e.g. dry density, hardness and stability) of the four commercial Entandrophragma species are summarized in table III. They predispose these species to the timber industry, especially as their heartwood used outside wetlands is also known to resist attack by fungi, dry wood insects and termites (Staner et al., 1958; Gérard et al., 2016).

\section{Economic value}

Entandrophragma species as well as those of Swietenia Jacq. and Khaya A. Juss. are listed under the Anglo-Saxon name of Mahogany, which includes the best woods for cabinet-making worldwide (White and Gasson, 2008). African mahogany includes the genera Khaya and Entandrophragma, which are among the most valuable forest species and are traded in significant volumes, accounting for more than $70 \%$ of the total volume exported from CAR (Hall, 2008) for example. Entandrophragma is the only genus of which five species are extracted from Africa's dense tropical forests (Staner et al., 1958; Bayol et al., 2012). To understand the economic importance of these species and the threats to their future, it would be important to know how harvests in their range have evolved since the 1960s on a country-by-country basis, in order to follow the migration of logging areas over time. 


\section{Distribution area}

Six species of Entandrophragma are very widely distributed across the Guinean-Congolese zone: E. angolense, E. candollei, E. congoense, E. cylindricum, E. palustre and E. utile (Kasongo Yakusu et al., 2018). With the exception of E. palustre, which is restricted to swamp forests, mainly in DRC and the Republic of the Congo (Lemmens, 2008), the other five species grow in dense evergreen and semi-deciduous tropical forests (Meunier et al., 2015; Kasongo Yakusu et al., 2018). Figure 1 shows the geographical distribution of these species, adapted from the "Rainbio" database (Dauby et al., 2016). E. cylindricum and E. angolense have the widest distribution and are locally more abundant than E. candolei and E. utile (Doumenge et al., 2010; Kasongo Yakusu et al., 2018).

\section{Concentration of production in West Africa}

Statistics (from the 1960s onwards) on timber production in logs or exports by type of product (e.g. logs, sawn wood, peeled veneer and plywood) and by Entandrophragma species are rarely available and accessible. Moreover, they are not regular and not chronologically continuous. From data published in the Bois et Forêts des Tropiques journal between 1963 and 1974 under the heading "Commerce des bois tropicaux", it is possible to track Entandrophragma log exports from 1963 to 1973 from Côte d'Ivoire, Cameroon and Gabon. Although they are patchy, ATIBT statistics can be used to draw out figures for Gabon for the 1998-2003 period. Large quantities of Entandrophragma logs were exported during 1963-1973: \pm 6 million $\mathrm{m}^{3}$ of sipo, \pm 1.5 million $\mathrm{m}^{3}$ of sapelli and \pm 5 million $\mathrm{m}^{3}$ of white tiama from Côte d'Ivoire; $\pm 350,000 \mathrm{~m}^{3}$ of sapelli, $\pm 150,000 \mathrm{~m}^{3}$ of sipo and $\pm 40,000 \mathrm{~m}^{3}$ of kosipo from Cameroon; $\pm 200,000 \mathrm{~m}^{3}$ of sipo, $\pm 150,000 \mathrm{~m}^{3}$ of sapelli and $\pm 75,000 \mathrm{~m}^{3}$ of tiama from Congo and $\pm 25,000 \mathrm{~m}^{3}$ of sipo, $\pm 15,000 \mathrm{~m}^{3}$ of white tiama and $\pm 7,000 \mathrm{~m}^{3}$ of sapelli from Gabon. Figure 2 shows these exports by year. For the 1996-2013 period, only the statistics for Gabon are available: this country exported $\pm 200,000 \mathrm{~m}^{3}$ of Entandrophragma.

Côte d'Ivoire is the country where commercial Entandrophragma species have been most heavily logged (around 10 million $\mathrm{m}^{3}$ of logs extracted between 1963 and 1973). Together with the encroachment of agricultural land into forest areas, this has greatly reduced the resource. From the mid-1970s onwards, exports began to decline (figure 2) and by the 2000s, the resource had been exhausted. Statistics on the number of logs entering sawmills then only concern $E$. angolense, with $41,700 \mathrm{~m}^{3}$ of logs in 2004 and $10,400 \mathrm{~m}^{3}$ in 2012 (Louppe and Ouattara, 2013), the other species of the genus being extracted only in small quantities.

\section{Central Africa, a new reservoir for production}

Currently, logging of these species has shifted to other regions. Table IV shows this shift between 2005 and 2012, during which time controlled production, production of Entandrophragma logs in Central Africa was as follows:

- sapelli: Congo \pm 3.5 million $\mathrm{m}^{3}$, Cameroon \pm 3 million $\mathrm{m}^{3}$, CAR \pm 2 million $\mathrm{m}^{3}$ and $\mathrm{DRC} \pm 500,000 \mathrm{~m}^{3}$;

- sipo: Congo $\pm 550,000 \mathrm{~m}^{3}, \mathrm{DRC} \pm 200,000 \mathrm{~m}^{3}$ and CAR $\pm 150,000 \mathrm{~m}^{3}$

- kosipo: Cameroon $\pm 300,000 \mathrm{~m}^{3}, \mathrm{CAR} \pm 150,000 \mathrm{~m}^{3}$, Congo $\pm 75,000 \mathrm{~m}^{3}$ and $\mathrm{DRC} \pm 50,000 \mathrm{~m}^{3}$; and

- white tiama: CAR $\pm 100,000 \mathrm{~m}^{3} ; \mathrm{DRC} \pm 100,000 \mathrm{~m}^{3}$.

In the early 2010s, Congo and Cameroon were the main producers of Entandrophragma timber (Bayol et al., 2012). The history of trade in sapelli clearly illustrates the scale of extraction of species of the genus. In West Africa, logging has greatly reduced populations of sapele, so that it has shifted to Central Africa, currently the main production centre (Eckebil et al., 2017) where it is by far the most heavily logged mahogany species with \pm 1.3 million $\mathrm{m}^{3}$ in 2008 (Bayol et al., 2012). Extraction of sipo and kosipo is low in comparison with $\pm 130,000$ and $\pm 100,000 \mathrm{~m}^{3}$, respectively, in 2008 (figure 3). In Central Africa, in 2008, only okoume (Aucoumea klaineana) was extracted in greater quantities than sapelli. The low volumes of sipo can be explained by its widely scattered distribution in the forest massif, which has led some forest managers to exclude it from the main target species (Bayol et al., 2012).

\section{Social value}

\section{Multiplicity of social uses}

Entandrophragma has multiple uses that are well known to local people (table V). They use the different parts of the tree to satisfy needs for food (e.g. collecting caterpillars), construction, handicrafts, medicines, livelihoods, economy
Figure 1.

Geographical distribution of the main commercial species of the genus Entandrophragma (map adapted from the "Rainbio" database; Dauby et al., 2016). 

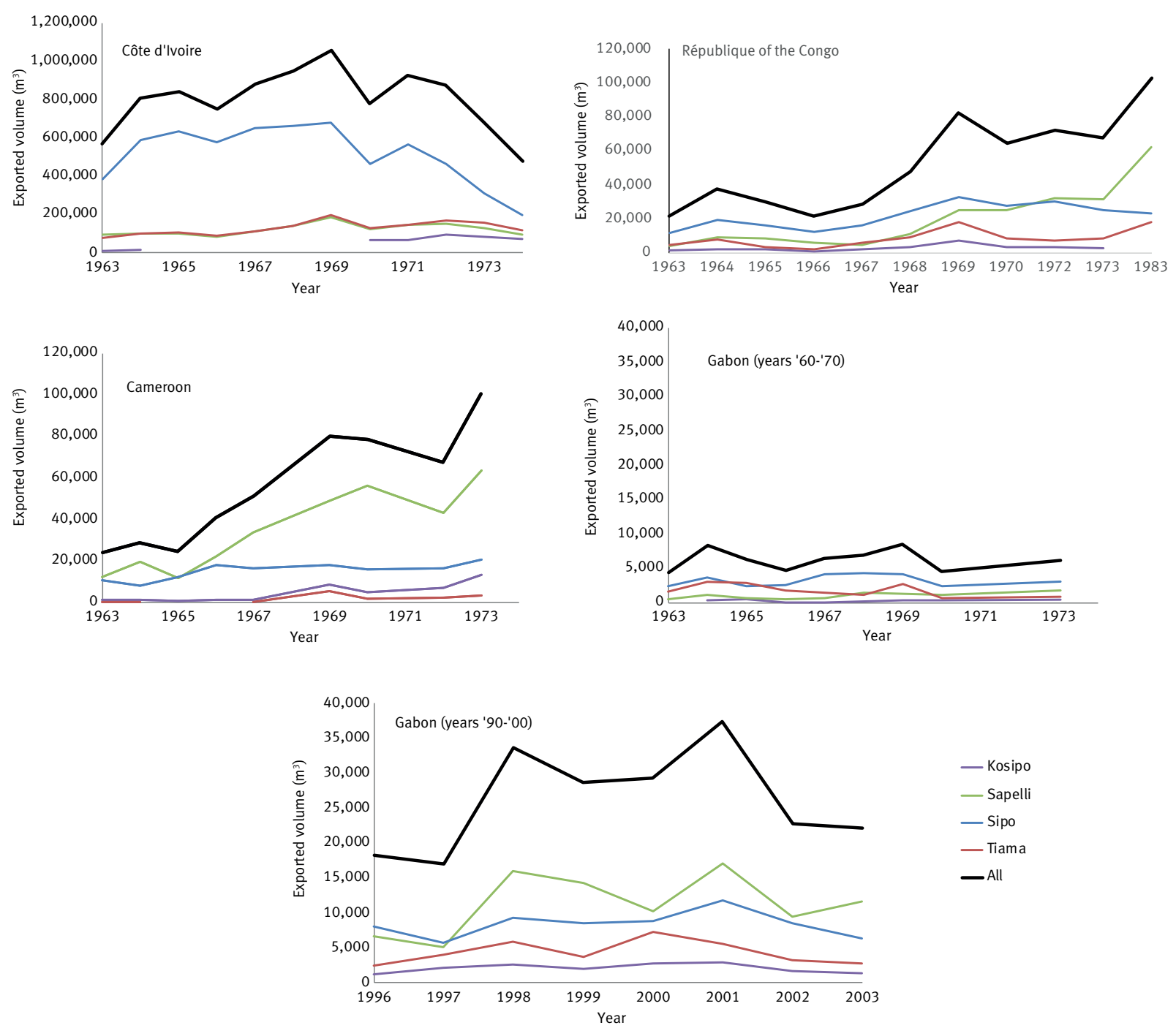

Figure 2.

Entandrophragma timber exports from Côte d'Ivoire (1963 to 1973), Cameroon (1963 to 1973), Congo (1963 to 1973) and Gabon (1963 to 1973 and 1998 to 2003).

Sources: before 1973, Bois et Forêts des Tropiques; after 1998, ATIBT newsletter.

and transport (dugout canoes), and others. (table V). The bark of all these species is used as medicine against various diseases. The roots of $E$. candollei are used as an anti-venom against snake bites. The seeds of Entandrophragma (e.g. E. angolense) are rich in oils that deserve detailed studies on their properties, including toxicity (Lemmens et al., 2010). In view of their multiple medicinal uses, it would be advisable to conduct additional pharmacological studies on the bark and roots and chemical analyses to identify the active molecules.

\section{Analysis and management of potential social conflicts}

Some uses can have both positive and negative impacts on Entandrophragma stands and are therefore a source of conflict between local communities and logging concession managers (e.g. tree felling limits possibilities for collecting caterpillars). Edible caterpillars of the species Imbrasia oyemensis, which infest large sapelli, are harvested between July and August (Palla et al., 2002; Eckebil et al., 2017). It has sometimes been observed that collecting for food or medicinal purposes has led to trees being felled instead of conserved by users. This use of non-timber forest products by forest populations is in opposition to industrial logging (Vermeulen et al., 2009) and can generate conflicts between logging operators and surrounding populations. Inclusive management of production forests in Central Africa should therefore be considered to avoid or reduce these conflicts (Karsenty and Vermeulen, 2016). This management model is observed, for example, in northern Congo, where FSC (Forest Stewardship Council) certified logging companies mark the caterpillar-infested sapelli trees with the local population to prevent them from being felled. In addition to this effective participatory approach, the CFT (Compagnie Forestière et de Transformation) (2015) recommends conducting an analysis of potential use conflicts village by village during the preparation of annual logging plans, so that measures can be taken to reduce the social impact, in particular by protecting trees that are important to local populations. Tieguong et 
Table IV.

Entandrophragma timber production (volumes felled in $\mathrm{m}^{3}$ ) from 2005 to 2012 in Cameroon, Republic of the Congo, Central African Republic and Democratic Republic of the Congo (adapted from de Wasseige et al., 2014).

\begin{tabular}{|c|c|c|c|c|c|c|c|c|c|c|c|c|c|c|c|c|}
\hline \multirow[t]{2}{*}{ Date } & \multicolumn{3}{|c|}{ Cameroon } & \multirow[b]{2}{*}{ Tiama } & \multicolumn{4}{|c|}{ Republic of the Congo } & \multicolumn{4}{|c|}{ Central African Republic } & \multicolumn{4}{|c|}{ Democratic Republic of the Congo } \\
\hline & Kosipo & Sapelli & Sipo & & Kosipo & Sapelli & Sipo & Tiama & Kosipo & Sapelli & Sipo & Tiama & Kosipo & Sapelli & Sipo & Tiama \\
\hline 2005 & 41,315 & 378,756 & - & - & 4,320 & 496,547 & 72,906 & - & 6,786 & 215,220 & 21,896 & 3,095 & 4,189 & 34,792 & 20,565 & 9,669 \\
\hline 2006 & 45,367 & 377,142 & - & - & 12,177 & 316,098 & 75,971 & - & 17,174 & 335,604 & 28,909 & 14,399 & - & 65,465 & 31,773 & 11,992 \\
\hline 2007 & 43,751 & 395,469 & - & - & 29,641 & 295,221 & 80,076 & - & 24,033 & 295,954 & 21,098 & 14,561 & - & 60,914 & 26,952 & 10,986 \\
\hline 2008 & 46,151 & 408,068 & 30,901 & - & 13,269 & 343,652 & 35,749 & - & 3,0921 & 271,283 & 28,329 & 16,493 & 8,303 & 56,542 & 30,537 & 15,716 \\
\hline 2009 & 35,267 & 264,771 & - & - & - & 412,406 & 128,530 & - & 12,548 & 188,206 & 17,359 & 5,176 & 12,768 & 62,079 & 39,356 & 17,312 \\
\hline 2010 & - & 343,797 & - & - & - & 540,563 & 53,641 & - & 16,798 & 185,619 & - & 5,931 & - & 68,561 & 15,964 & 10,416 \\
\hline 2011 & - & 365,446 & - & - & - & 546,440 & 49,035 & - & 22,050 & 215,616 & 13,937 & 17,623 & - & 79,811 & 15,902 & 5,714 \\
\hline 2012 & 43,717 & 375,729 & - & - & - & 449,456 & 52,379 & - & - & - & - & - & - & - & - & - \\
\hline Total & 255,568 & $2,099,178$ & 30,901 & - & 59,407 & $3,400,383$ & 548,287 & - & 130,310 & $1,707,502$ & 131,528 & 77,278 & 2,726 & 428,164 & 181,049 & 81,805 \\
\hline
\end{tabular}

al. (2017) emphasize the need for information on the availability and accessibility of multiple-use tree species in order to negotiate management agreements that satisfy both concession holders and local communities. Thus, certain populations of sapelli or other Entandrophragma species of high commercial value present in village lands should be classified as Type 5 High Conservation Value Zones ("forest areas providing local communities with the resources necessary to meet their basic needs [...]") (Daïnou et al., 2016).

\section{Management of Entandrophragma populations}

\section{Conservation status}

\section{Brief overview of the classification method}

The four main Entandrophragma species (for a long time considered similar to white tiama, very few data exist on the ecology of black tiama. Despite this, black tiama is different to white tiama morphogically and genetically; Monthe et al., 2018) are classified as "Vulnerable" on the IUCN Red List (IUCN, 2012). However, none of them are listed in CITES Appendix I ("includes all species threatened with extinction [...]”; CITES, 1983) or Appendix II ("includes all species that might be threatened with extinction if trade in specimens of such species were not subject to strict regulation [...]"; CITES, 1983). A taxon is said to be "vulnerable" when the best available data (Sépulchre et al., 2008) indicate that it meets, to a very precise degree, one of the following 5 criteria: reduction of the population, fragmented or declining geographical distribution (area of occurrence and area of occupancy), small and declining population (number of mature individuals), very small or restricted population, more than $50 \%$ probability of extinction within 10 years of three generations. Parts of this methodology proposed by the IUCN have been questioned by Sépulchre et al. (2008) because some criteria, which are difficult to quantify, are derived from estimates (of adult individuals) at the worldwide level. The IUCN has considered developing "regional" and/or "sub-regional” red lists (Sépulchre et al.,
Figure 3.

Estimated 2008 production by species in the Congo Basin $\left(\mathrm{m}^{3}\right)$ (Bayol et al., 2012). Okoumé: Aucoumea klaineana; Sapelli: Entandrophragma cylindricum; Ayous: Triplochiton scleroxylon; Tali: Erythrophleum spp.; Okan: Cylicodiscus gabonensis; Azobé: Lophira alata; Padouk: Pterocarpus soyauxii; Sipo: Entandrophragma utile; Iroko: Milicia excelsa; Kosipo: Entandrophragma candollei; Wenge: Millettia laurentii; Fraké: Terminalia superba; Bossé: Leplaea spp. 
Tableau V.

Social uses of the four main commercial Entandrophragma species.

\begin{tabular}{|c|c|c|c|c|}
\hline $\begin{array}{l}\text { Used } \\
\text { parts }\end{array}$ & $\begin{array}{l}\text { Entandrophragma angolense } \\
\text { (white tiama) }\end{array}$ & $\begin{array}{l}\text { Entandrophragma } \\
\text { candollei (kosipo) }\end{array}$ & $\begin{array}{l}\text { Uses } \\
\text { Entandrophragma cylindricum (sapelli) }\end{array}$ & Entandrophragma utile (sipo) \\
\hline Trees & $\begin{array}{l}\text { Used in agroforestry as an } \\
\text { alignment and shade tree. }\end{array}$ & & $\begin{array}{l}\text { Used in agroforestry as an } \\
\text { alignment, ornamental and shade } \\
\text { tree. Hosts edible caterpillars. }\end{array}$ & \\
\hline Wood & $\begin{array}{l}\text { Coffins, musical } \\
\text { instruments, toys, } \\
\text { sculptures, timbering, } \\
\text { firewood and charcoal. }\end{array}$ & $\begin{array}{l}\text { Timber, toys and } \\
\text { novelty items. }\end{array}$ & $\begin{array}{l}\text { Musical instruments, sculpture, } \\
\text { toys, novelty items, manufacture } \\
\text { of monocoque dugout canoes, } \\
\text { timbering, firewood and charcoal. }\end{array}$ & $\begin{array}{l}\text { Sculpture, dugout canoes, } \\
\text { timbering, firewood and } \\
\text { charcoal. }\end{array}$ \\
\hline Bark & $\begin{array}{l}\text { Its decoction is drunk to } \\
\text { treat fever and the bark } \\
\text { is used as an analgesic } \\
\text { for stomach aches, peptic } \\
\text { ulcers, earache, kidney, } \\
\text { rheumatic or arthritic pain, } \\
\text { eye infections, oedema and } \\
\text { ulcers. }\end{array}$ & $\begin{array}{l}\text { Yellow fever, } \\
\text { malaria, typhoid. } \\
\text { Used as an } \\
\text { analgesic. }\end{array}$ & $\begin{array}{l}\text { Its decoctions or macerations are } \\
\text { used against malaria, bronchitis, } \\
\text { lung ailments, colds, oedemas } \\
\text { and as an analgesic; the pulp } \\
\text { against boils and wounds. Its } \\
\text { extracts were once used as a } \\
\text { protective agent for stored maize. }\end{array}$ & $\begin{array}{l}\text { Juice used for stomach and } \\
\text { kidney pains, rheumatism, } \\
\text { eye baths, inflammations, } \\
\text { ear infections, headaches, } \\
\text { malaria and peptic ulcers. }\end{array}$ \\
\hline Leaves & - & - & $\begin{array}{l}\text { Hosts the edible caterpillars of the } \\
\text { Imbrasia oyemensis butterfly. }\end{array}$ & Hosts edible caterpillars. \\
\hline Seeds & $\begin{array}{l}\text { Rich source of oil (about } \\
60 \% \text { fat content). }\end{array}$ & - & $\begin{array}{l}\text { Source of oil (approx. } 45 \% \text { fat } \\
\text { content). }\end{array}$ & $\begin{array}{l}\text { Source of oil (approx. } \\
30-54 \% \text { fat content) and } \\
\text { essential oil. }\end{array}$ \\
\hline Root & - & $\begin{array}{l}\text { The root bark is } \\
\text { applied to snake } \\
\text { bites. }\end{array}$ & - & - \\
\hline References & Tchinda, 2008. & $\begin{array}{l}\text { Dibong et al., 2011; } \\
\text { Nyunaï, } 2008\end{array}$ & $\begin{array}{l}\text { Jagoret et al., 2014; Mate et al., 2013; } \\
\text { Lisingo et al., 2012; Dibong et al., } \\
\text { 2011; Kémeuzé, } 2008\end{array}$ & $\begin{array}{l}\text { Mate et al., 2013; Lisingo et al., } \\
\text { 2012; Mujuni, 2008; Onifade, } \\
2006\end{array}$ \\
\hline
\end{tabular}

2008), which would allow a better assessment of the risk to species at the local level. It can thus be assumed that Entandrophragma from Côte d'Ivoire could be classified as "endangered" due to over-logging and drastic reduction of its habitat following land use changes.

\section{Intensification of logging}

Intensive logging of Entandrophragma in Central Africa could, as in West Africa, compromise the sustainability of these species. This situation varies from one species to another and from one region to another. In Central Africa, sapelli was still abundant in 2008 despite intensive logging in northern Congo, south-western CAR and DRC. At the time, this species did not show any obvious signs of vulnerabi- lity (Sépulchre, 2008), but as it provides one of the most commercially important timbers in Africa, it is still being exploited without sufficient efforts to ensure that logging is sustainable (Kémeuzé, 2008). There is therefore a risk that the scenario observed in West Africa, where exploitable trees have practically disappeared to the extent that some industrialists in Côte d'Ivoire now import sapelli from Congo (Louppe and Ouattara, 2013), will be repeated. Moreover, some industrial groups prefer to transport raw or only partially processed products from Central Africa to West Africa, where processing units with trained personnel have been established. In the absence of specific management measures for $E$. utile, Sépulchre et al. (2008) consider the species to be threatened despite a fairly good population 
structure showing the existence of satisfactory natural regeneration. Commercial interest in its timber has led to the extraction of the largest and most standards-compliant individual trees from the forests of Côte d'Ivoire, Ghana, Nigeria, Cameroon, CAR and Uganda. As a result, in Uganda for example, the species is on the brink of extinction (Mujuni, 2008). E. angolense is also threatened with genetic erosion in the near future and is considered to be under threat in Ghana and Uganda (Tchinda, 2008) and close to extinction in Kenya (Fischer et al., 2010). E. candollei, whose timber is somewhat less valued, is nevertheless being logged in many areas on a probably unsustainable basis (Nyunaï, 2008). The data presented above are almost a decade old. Since then, due to numerous habitat modifications, increasing pressure on these species, the scale of poorly controlled

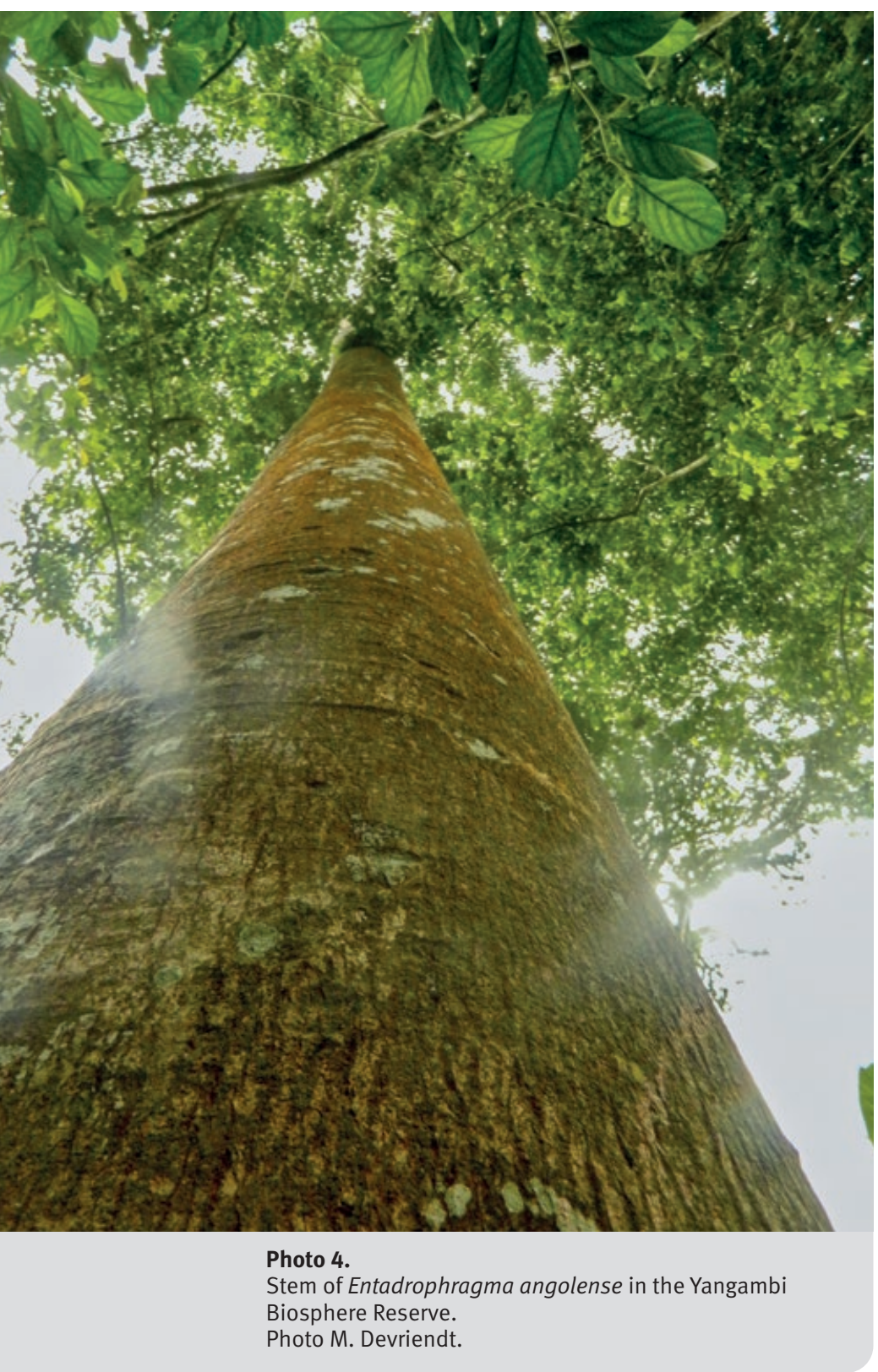

artisanal logging and inadequate enforcement of regulations and sustainable management measures, the situation has probably worsened. There is therefore an urgent need to reassess the vulnerability of each Entandrophragma species in each country so that appropriate management measures can be recommended.

\section{Skimming and management of tree populations}

In the absence of management plans, selective commercial logging has led to over-exploitation of some valuable species (redwoods such as mahogany, sipo, sapelli or lighter woods such as okoumé) and low exploitation of (many) others (Karsenty, 2004). This selective extraction, combined with poor regeneration, low growth rates, late seed maturity and poor seed dispersal, is leading to genetic erosion in some Entandrophragma species which is threatening the genetic quality of populations, at least in some countries (Lemmens et al., 2010). In the specific case of E. cylindricum, Lourmas et al. (2007) showed that the reduction in the number of seed trees following logging is resulting more in a regeneration deficit than in a problem of genetic diversity. This deficit of future stems compromises logging sustainability if no specific management system is applied (Sépulchre et al., 2008). Felling restrictions (e.g. increasing minimum cutting diameters) in order to conserve seed trees and provide "assistance" for regeneration are among the corrective measures recommended (Owona Ndongo, 2006; Lourmas et al., 2007; Sépulchre et al., 2008; Doucet et al., 2016). In this context, ecological studies on Entandrophragma regeneration should be carried out by comparing recently logged forests with unlogged or formerly logged forests in order to better understand the reproductive processes (flowering and fruiting phenology, pollen and seed dispersal in subsequent work by Lourmas et al. (2007) and Monthe et al. (2017) as well as the ecological conditions determining seedling establishment, survival and growth and the biotic and abiotic risks they present. 


\section{Sustainable management policy, legislation and regulation}

\author{
Categorization and implementation \\ of sustainable management systems
}

The operational implementation of sustainable management systems for tropical forests focuses on a relatively small number of categories, i.e. in the majority of cases, management systems aim to improve either industrial and artisanal forestry (forest management, low impact logging, forest certification, reforestation, etc.) or to reinforce carbon storage (Clean Development Mechanism - CDM/Forests, REDD, etc.) or, finally, to increase the involvement of local populations in forest management and use (participatory management, community-based management, etc.; Leroy et al., 2011). Currently, these three categories tend to overlap. Effective implementation of these tools or regulatory instruments would make it possible to strengthen the sustainable management of forest species. Some management tools designed to improve forest management (artisanal and industrial logging methods) and to increase wood and carbon stocks (reforestation policy) of Entandrophragma are discussed in the following section.

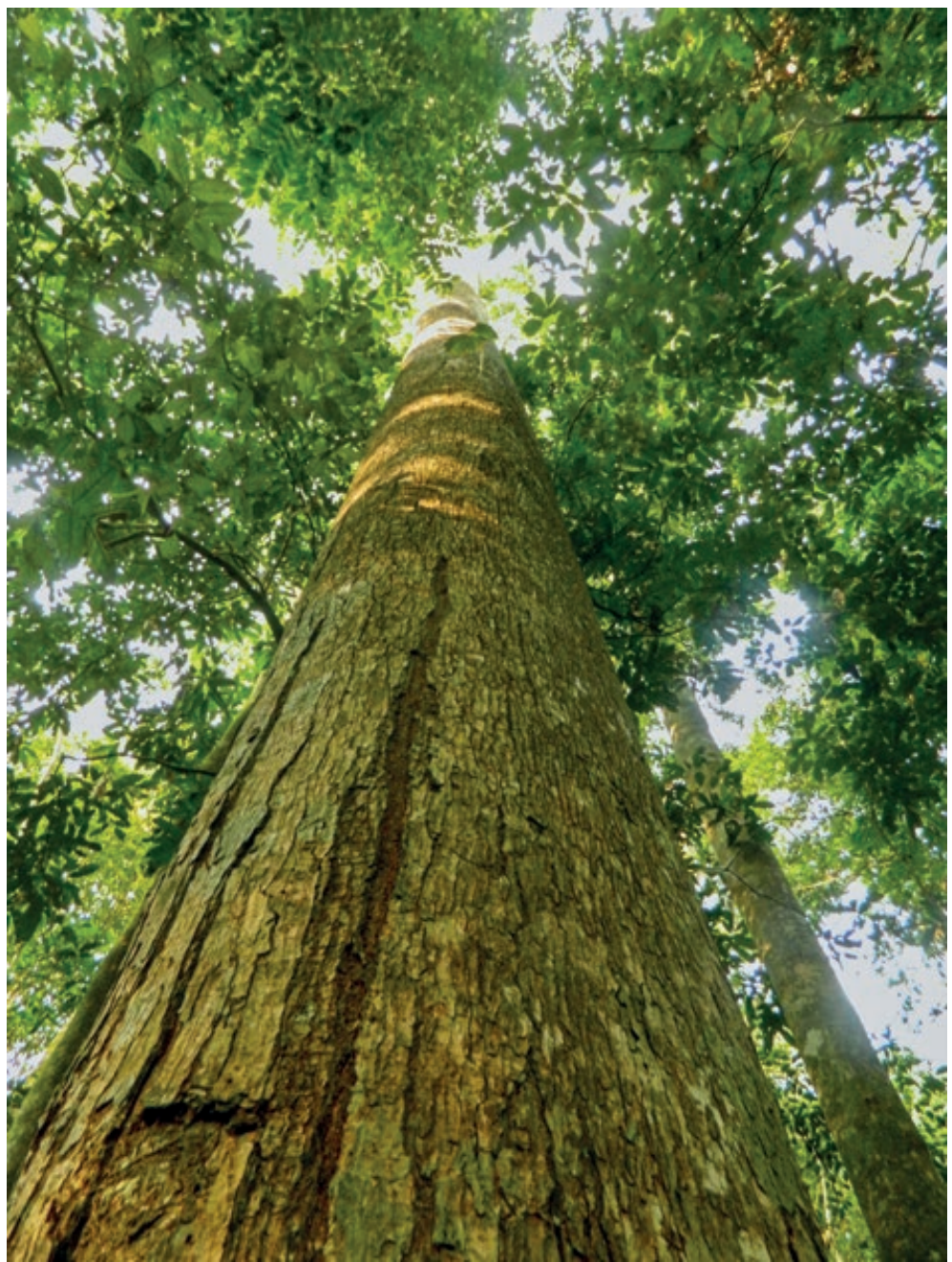

Photo 5.

Entandrophragma utile stem in the Yangambi

Biosphere Reserve.

Photo M. Devriendt.

\section{Effective implementation of forest management plans}

\section{Sectoral approach extended to the valuation of wood and carbon stocks}

In Central Africa, studies for the implementation of forest management plans (FMPs) were developed in the 1990s (Marien and Mallet, 2004). In theory, FMPs assess the potential of the resource, take into account the tradeoffs between ecological, economic and social aspects and propose balanced solutions (Cerutti et al., 2017). In practice, forest management must ensure the conservation of resources as well as the well-being of the population, and forestry must provide the technical solutions (Dupuy, 1998). In addition, implementing an FMP is also an opportunity to reduce forest carbon emissions while presenting forest enterprises with acceptable financial trade-offs (Cerutti et al., 2017).

\section{Sustained attention to a few specific rules and actions}

To avoid compromising regeneration and to boost the dynamics of a logged forest, Fargeot et al. (2004) propose giving priority to two management instruments or tools: the duration of the rotation, which is based in particular on economic and auto-ecological considerations, and the determination of minimum diameters in exploitable areas that take into account, at least ideally, ecological and technical imperatives. In addition to low-impact extraction techniques, these two management tools must be included in the effective implementation of FMPs. According to Karsenty (2004), the absence of management rules can raise serious problems for the renewal of the resource in unmanaged concessions but also, and probably above all, in forests where informal artisanal logging takes place. The renewal of over-exploited commercial Entandrophragma species will therefore require the development, validation and implementation of PAFs and compliance with them. Sustainable forest management is also relevant to the certification of good forest management (FSC, African Forest Certification Programme -AFCP-, etc.) or legality (Timber Origin and Legality -OLB-, Timber Legality \& Traceability Verification -TLTV-, Verification of Legal Origin/Compliance -VLO/VLC-, etc.) (Karsenty and Ferron, 2017). To achieve this, Bayol et al. (2010) suggest building the capacity of forest law enforcement institutions in a context of strengthened rule of law (i.e. through strict law enforcement) when forest concessions are not managed or are slow to use the management tools discussed above.

\section{Revision of minimum logging diameters}

The Minimum Logging Diameter (MLD), the legal threshold at which a tree can legally be felled, for Entandrophragma species varies from country to country (table V). Côte d'Ivoire, where Entandrophragma species have been over-exploited since the 1960s, had set the MLE at the lowest level: $60 \mathrm{~cm}$. In contrast, Ghana has set the MLD for all Entandrophragma species at the 
highest level: $110 \mathrm{~cm}$. Ghana, Cameroon and Liberia are the three countries that have increased the MLD for sapelli (to $110 \mathrm{~cm}, 100 \mathrm{~cm}$ and $90 \mathrm{~cm}$ respectively) in order to improve the rate of recovery of the resource. The MLD for kosipo has been set at $80 \mathrm{~cm}$ by all central African exporting countries.

The regular fruiting diameter (RFD), the threshold at which efficient and regular fruiting takes place, is one of the important parameters to be taken into account to ensure logging sustainability. The RFD-MLD comparison (table VI) helps to assess the risk of shortage of seed trees and their regeneration. In order to avoid too great a reduction in the number of seed trees, it is necessary to ensure that RFD-MLD are significantly larger than the regular fruiting diameters (Durrieu de Madron et al., 2004; Sépulchre et al., 2008; Tchinda, 2008; Mujuni, 2008; Nyunaï, 2008; Kézeumé, 2008; Daïnou and Doucet, 2010). As future harvest is a function of the size of the diameter classes below the DME and of increment, logging damage and mortality (Durrieu de Madron and Forni, 1997), it is important to revise the regulation on the Entandrophragma DME by formalising an increase in RFD in all African producer countries. Fargeot et al. (2004) show that, for the same rotation period, a simple increase in MLD demands the maintenance of larger standing trees and increases the production of exploitable wood

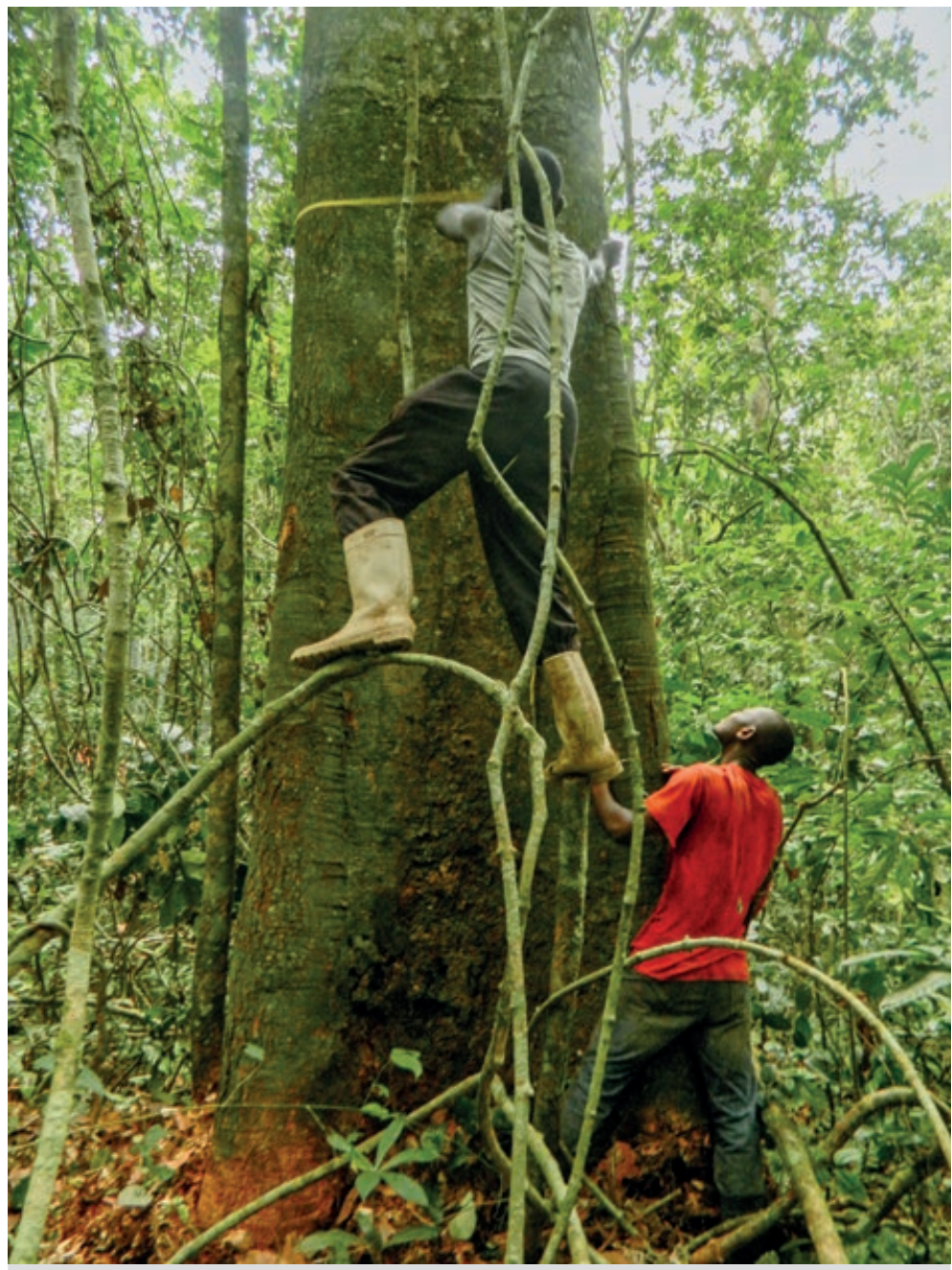

Photo 6.

Measuring the increase in diameter of a trunk of Entandrophragma cylindricum.

Photo M. Devriendt. from the forest. This regulatory requirement should apply to all forest concession holders, including those who do not yet have MFPs and should therefore not be allowed to log. As part of a commitment to sustainable management, states should cancel the contracts of concession holders who do not yet have an MFP after the 3-year interim agreement to produce one.

\section{Regulation of artisanal and informal logging}

In the Congo Basin, the domestic timber market is growing strongly in terms of quantity, but the low purchasing power of the populations and the absence of client demands in terms of resource management mean that this market is almost systematically geared to the informal and/or illegal sector (Bayol et al., 2014), so much so that log production in the informal sector may even exceed production in the formal sector (Bayol et al., 2012). Recent studies in Cameroon, Gabon, CAR and DRC by Lescuyer et al. (2012) show that the domestic market for wood from artisanal, often informal, sawmills has reached an overall annual production of about 1.25 million $\mathrm{m}^{3}$ of processed products, higher than in the controlled industrial sector. All these studies show that artisanal operators consider Entandrophragma, and some other species (e.g. Khaya anthotheca (Welw.) C. DC., Pericopsis elata (Harms) Meeuwen, Pterocarpus soyauxii Taub., Milicia excelsa (Welw.) C.C. Berg.), as noble woods and target them specifically (Tshimpanga et al., 2016). To improve the safety of artisanal logging, increase its contribution to the national economy and control its environmental impacts, Tiayon and Molnar (2012) recommend better control and formalization of the artisanal sawmilling sector.

\section{Need to strengthen reforestation policy and measures}

According to Marien and Mallet (2004), central African countries began to study possibilities for enriching their forest heritage in 1934, by planting arboretums in Mbuku Nsitu in the Mayombe massif (Congo), in Sibang outside Libreville (Gabon) and several other sites (Mbalmayo in Cameroon, Yangambi in DRC). State programmes were then set up to enrich these arboreta by planting commercially valuable species (sipo, sapelli, etc.) along the forest inventory strips in natural forests being logged in northern Congo, Cameroon and DRC (Yangambi). These programmes were abandoned fairly quickly and replaced by, for example, plantations of exotic species or okoumé. On a more modest scale, some peasant farmers in western Cameroon, for example, are planting kosipo in their hedgerows, which is considered as a natural forest species producing long rotation wood (Temgoua et al., 2011).

In Côte d'Ivoire, when the deforestation rate reached 600,000 ha/year during the 1960-1970 decade, the country turned to reforestation, which was in full swing (Alexandre, 1982) when programmes to enrich natural forests had already been abandoned. The lack of knowledge of natural regeneration mentioned by Catinot (1965), still poorly mastered to date (Doucet et al., 2016), is one of the obstacles to extensive techniques for renewing and enriching natural forest capital. 
Table VI.

Minimum Fruiting Diameter (MFD), Regular Fruiting Diameter (RFD) and Minimum Logging Diameter (MLD) of Entandrophragma tree species.

RC: Republic of the Congo; Cam: Cameroun; DRC: Republic Democratic of the Congo; CAR: Central African Republic; Cl: Côte d'Ivoire. (Source: Kasongo Yakusu et al., 2018).

\begin{tabular}{|c|c|c|c|c|c|c|}
\hline Species & Scientific name & MFD (cm) & RFD (cm) & MLD (cm) & Country & Reference \\
\hline \multirow[t]{9}{*}{ Kosipo } & \multirow{9}{*}{$\begin{array}{l}\text { Entandrophragma } \\
\text { candollei }\end{array}$} & 40 & - & 80 & CAR & Yalibanda, 1999 \\
\hline & & - & 85 & 70 & Uganda & Plumptre, 1995 \\
\hline & & \multirow{7}{*}{-} & \multirow{7}{*}{-} & 110 & Ghana & \multirow[t]{7}{*}{ Nyunaï, 2008} \\
\hline & & & & 90 & Liberia & \\
\hline & & & & 60 & $\mathrm{Cl}$ & \\
\hline & & & & \multirow[t]{4}{*}{80} & Gabon & \\
\hline & & & & & $\mathrm{RC}$ & \\
\hline & & & & & Cam & \\
\hline & & & & & DRC & \\
\hline \multirow[t]{11}{*}{ Sapelli } & \multirow[t]{11}{*}{$\begin{array}{l}\text { Entandrophragma } \\
\text { cylindricum }\end{array}$} & - & 75 & 80 & CAR & $\begin{array}{l}\text { Durrieu de Madron } \\
\text { and Daumeurie, } 2004\end{array}$ \\
\hline & & - & 85 & - & Uganda & Plumptre, 1995 \\
\hline & & 35 & - & 80 & CAR & Petrucci et al., 1995 \\
\hline & & 55 & & 80 & CAR & Yalibanda, 1999 \\
\hline & & 40 & 55 & 90 & Gabon & Sépulchre et al., 2008 \\
\hline & & \multirow{6}{*}{-} & \multirow{6}{*}{-} & 60 & $\mathrm{Cl}$ & \multirow[t]{6}{*}{ Palla et al., 2002} \\
\hline & & & & 110 & Ghana & \\
\hline & & & & 90 & Liberia & \\
\hline & & & & 80 & $\mathrm{RC}$ & \\
\hline & & & & 100 & Cam & \\
\hline & & & & 80 & DRC & \\
\hline \multirow[t]{8}{*}{ Sipo } & \multirow{8}{*}{$\begin{array}{l}\text { Entandrophragma } \\
\text { utile }\end{array}$} & - & 85 & 90 & Gabon & Sépulchre et al., 2008 \\
\hline & & \multirow{7}{*}{-} & \multirow{7}{*}{-} & 110 & Ghana & \multirow[t]{7}{*}{ Mujuni, 2008} \\
\hline & & & & 100 & Cam & \\
\hline & & & & 90 & Liberia & \\
\hline & & & & 60 & $\mathrm{Cl}$ & \\
\hline & & & & 80 & $\mathrm{RC}$ & \\
\hline & & & & 80 & DRC & \\
\hline & & & & 80 & CAR & \\
\hline \multirow[t]{10}{*}{ Tiama } & \multirow{10}{*}{$\begin{array}{l}\text { Entandrophragma } \\
\text { angolense }\end{array}$} & 55 & - & 80 & CAR & Petrucci et al., 1995 \\
\hline & & 50 & - & 80 & CAR & Yalibanda, 1999 \\
\hline & & - & 85 & - & Uganda & Plumptre, 1995 \\
\hline & & \multirow{7}{*}{-} & \multirow{7}{*}{-} & 110 & Ghana & \multirow[t]{7}{*}{ Tchinda, 2008} \\
\hline & & & & 90 & Liberia & \\
\hline & & & & 60 & $\mathrm{Cl}$ & \\
\hline & & & & 80 & Gabon & \\
\hline & & & & 80 & $\mathrm{RC}$ & \\
\hline & & & & 80 & Cam & \\
\hline & & & & 80 & DRC & \\
\hline
\end{tabular}




\section{Conclusion and research perspectives}

In terms of forest plantations, strengthening of reforestation policies should take into account the multiple causes of failure identified by Marien and Gourlet-Fleury (2014): insufficient or faulty prior strategic analyses, approximate or unsuitable technical schemes, poor appreciation of social issues, failure to resolve land tenure issues (long-term security of land tenure, pressure for other uses, real estate or agricultural speculation), poor economic calculations, insufficiently documented environmental impacts, insufficient long-term financing, etc. To limit the depletion of over-exploited species, West and Central African countries do not have sufficient means to invest in large-scale plantations that will produce exploitable trees within a few decades. Developing agroforestry systems would make it possible to secure an annual income (e.g. from cocoa and coffee) and a one-off gain from logging over a longer period.

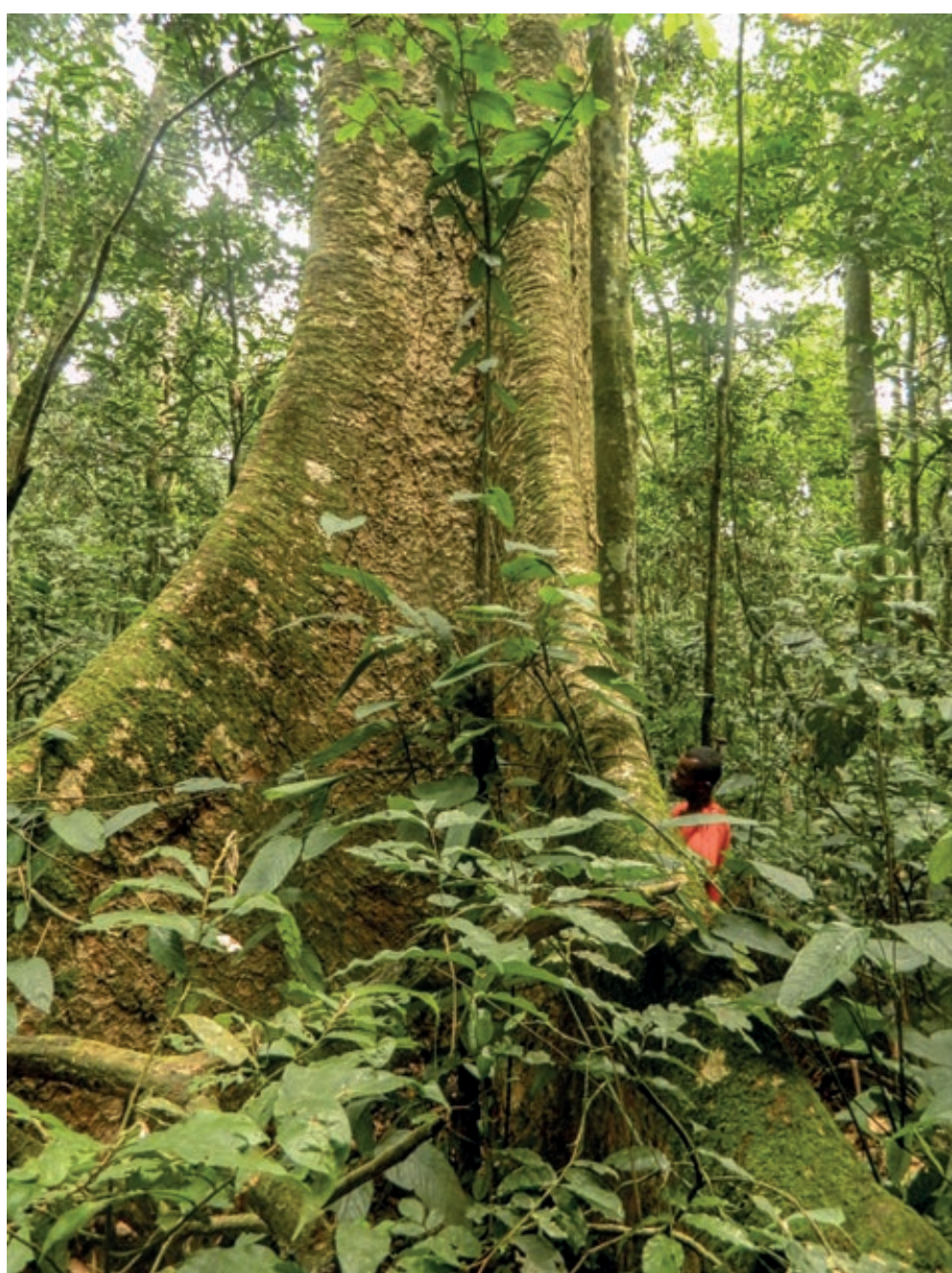

Photo 7.

Base of a stem of Entandrophragma angolense in the Yangambi Biosphere Reserve. Photo M. Devriendt.
This review of issues that arise for improvements in the management of the Entandrophragma genus in natural forests shows that this taxon is of significant economic interest, which has resulted in over-exploitation, both industrial and artisanal, initially in West Africa and now concentrated in Central Africa. Limited natural regeneration, moderate or low growth rates, failure to use low-impact logging techniques and especially the absence of MFPs or only partial and/or uncontrolled implementation, together with selective and intensive extraction are all threatening natural populations of Entandrophragma. These threats are also leading to genetic erosion of the genus, to a greater or lesser extent depending on regions. The multiple uses made of these species are a potential source of conflicts between stakeholders, populations and industrialists. If forest managers do not involve local populations (inclusive management) and do not respect their fundamental social rights and their rights to use the forest (e.g. for food and medicines), it is impossible to set up viable MFPs.

Furthermore, the environmental impacts caused by the skimming of Entandrophragma populations are poorly documented for industrial logging, and virtually ignored for artisanal logging. Because of this situation, the sustainability of these forest resources is coming more acutely into question, since the management tools that could mitigate the problem need to be analysed from an overall and interactive perspective to ensure their viability. These tools include the regulation and/or improvement of industrial and artisanal logging (e.g. regulation of MLDs and effective control of the artisanal sector), improvement of carbon storage (e.g. by reforestation) and greater involvement of local populations by promoting inclusive management to develop the traditional pharmacopoeia, caterpillar collection, reforestation policy (and measures), etc. The scientific studies that would make it possible to strengthen management guidelines and measures for commercial Entandrophragma species are still fragmentary and do not cover the entire range of the genus. For example, in DRC, where the greatest diversity of Entandrophragma species is found and where the main species are logged industrially and by small-scale operators, very few recent scientific studies have been undertaken. A number of topics need in-depth studies to improve the management of these species for sustainability and to update their conservation status (currently recognised as "vulnerable") according to their geographical distribution. To achieve this, more research is needed on the following in particular:

- Growth rings analysis to measure growth rates (e.g. as affected by climate change, by analysing the relationship between ring widths and rainfall) and studies of stable oxygen isotopes (ס180) for climate reconstructions;

- analysis of diametric growth through measurements based on larger numbers of trees across their entire range; 
- anatomical and technological properties to justify priority measures for sustainable management (e.g. reforestation, integration into forestry schemes and controlling the illegal timber trade);

- updating the geographical distribution of each of the main commercial species;

- the processes involved in the natural regeneration of species, particularly in logging areas;

- reproductive processes (flowering and fruiting phenology, pollen and seed dispersal);

- impacts of human activities (industrial and artisanal extraction) and the environment (e.g. climate change);

- evaluating the evolution of production stocks, biomass and carbon;

- harmonisation of forestry policies within the producer countries of valuable Entandrophragma timber aimed at improving their sustainable management.

\section{Acknowledgements}

The authors would like to thank the European Union for the financial assistance to this study through the "FCCC" project, implemented by CIFOR at the University of Kisangani, and the Royal Museum of Central Africa for the "ABIC" scientific internship grant $(2016,2017,2018)$ in Belgium. They also thank all the readers and reviewers behind the scenes for their contributions to the improvement of the final version of this article and all those who provided any assistance in researching and compiling the information related to this publication.

\section{References}

Adler D., 1989. Natural forest increment, growth and yield. In: Wong J. L. G. (ed.). Ghana forest inventory project seminar proceedings. London, United Kingdom, Overseas Development Administration, Accra, Ghana, Forestry Department, 47-52.

Alexandre D.-Y., 1982. Aspects de la régénération naturelle en forêt dense de Côte-d'Ivoire. Candollea, 37 : 579-588. https:// core.ac.uk/download/pdf/39875069.pdf

ATIBT (Association technique internationale des bois tropicaux), 1986. Atlas des bois tropicaux. Tome I. Afrique. Paris, France, ATIBT, 240 p.

Bayol N., Anquetil F., Bile C., Bollen A., Bousquet M., Castadot B., et al., 2014. Filière bois d'œuvre et gestion des forêts naturelles : les bois tropicaux et les forêts d'Afrique centrale face aux évolutions des marchés. In : De Wasseige C., Flynn J., Louppe D., Hiol Hiol F., Mayaux Ph. (éds). Les forêts du bassin du Congo État des forêts 2013. Neufchâteau, Belgique, Weyrich, 47-66.

Bayol N., Demarquez B., De Wasseige C., Eba’a R., Fisher J.-F., Nasi R., et al., 2012. La gestion des forêts et la filière bois en Afrique Centrale. In : De Wasseige C., de Marcken P., Bayol N., Hiol Hiol F., Mayaux P., Desclée B., et al. (éds). Les forêts du bassin du Congo - État des forêts 2010. Luxembourg, Office des publications de l'Union européenne, 41-61.

Beeckman H., 2016. Wood anatomy and trait-based ecology. IAWA Journal, 37 (2): 127-151. https://doi. org/10.1163/22941932-20160127

Brazier J. D., Franklin G. L., 1961. Identification of hardwoods. A microscope key. Forest Products Research Bulletin, 46, 96 p.
Catinot R., 1965. Sylviculture tropicale en forêt dense africaine. Bois et Forêts des Tropiques, $100: 5-18$. https://doi. org/10.19182/bft1965.100.a18965

Catinot R., 2018. Tropical silviculture in dense African forest (Part 1). Bois et Forêts des Tropiques, $336: 7-18$. https://doi. org/10.19182/bft2018.336.a31602

Cerutti P. O., Suryadarma D., Nasi R., Forni E., Medjibe V., Delione S., et al., 2017. The impact of forest management plans on trees and carbon: Modeling a decade of harvesting data in Cameroon. Journal of Forest Economics, 27: 1-9. https://doi. org/10.1016/i.jfe.2017.01.004

CFT (Compagnie forestière de transformation), 2015. Plan d'aménagement forestier. Superficie sous aménagement. Concessions 46/11 et 47/11. Kinshasa, République démocratique du Congo, CFT.

Cirad (Centre de coopération internationale en recherche agronomique pour le développement), 2015. Les principales caractéristiques technologiques de 245 essences forestières tropicales. Tropix 7.5.1.

CITES (Convention pour le commerce international des espèces de faune et flore sauvages menacées d'extinction), 1983. Texte de convention. Version amendée à Gaborone. https://cites.org/ fra/disc/text.php (consulté le 31/05/2017).

Couralet C., Sterck F. J., Sass-Klaassen U., Van Acker J., Beeckman H., 2010. Species-specific growth responses to climate variations in understory trees of a Central African rain forest. Biotropica, 42: 503-511. https://doi.org/10.1111/j.1744-7429.2009.00613.x Dahms K.-G., 1999. Afrikanische Exporthölzer. 3. Auflage. Leinfelden-Echterdingen, Deutschland, DRW-Verlag, 358 p.

Daïnou K., Doucet J.-L., 2010. Évaluation de l'aménagement et de l'état des populations des essences exploitées par le Groupe SEFAC. Wavre, Belgique, Nature +.

Daïnou K., Bracke C., Vermeulen C., Haurez B., De Vleeschouwer J.-Y., Fayolle A., et al., 2016. Hautes Valeurs de Conservation (HVC) dans les Unités Forestières d'Aménagement du Cameroun : concepts, choix et pratiques. Gembloux, Belgique, Presses agronomiques de Gembloux. http://hdl.handle. net/2268/201957

Dauby G., Zaiss R., Blach-Overgaard A., Catarino L., Damen T., et al., 2016. RAINBIO: a mega-database of tropical African vascular plants distributions. PhytoKeys, 74: 1-18. https://doi. org/10.3897/phytokeys.74.9723

Détienne P., Mariaux A., 1977. Nature et périodicité des cernes dans les bois rouges de Méliacées africaines. Bois et Forêts des Tropiques, 175 : 29-37. https://doi.org/10.19182/ bft1975.159.a19269

Détienne P., Oyono F., Durrieu L., Demarquez B., Nasi R., 1998. L'analyse des cernes : applications aux études de croissance de quelques essences en peuplements naturels de forêt dense africaine. Montpellier, France, Cirad-Forêt.

Dibong S. D., Mpondo E., Ngoye A., Kwin M. F., 2011. Plantes médicinales utilisées par les populations Bassa de la région de Douala au Cameroun. International Journal of Biological and Chemical Sciences, 5: 1105-1117. http://dx.doi.org/10.4314/ ijbcs.v5i3.72227

Doucet J.-L., Kouadio Y. L., 2007. Le moabi, une espèce « phare » de l'exploitation forestière en Afrique centrale. Parcs Réserves, 62 (2) : 25-31. http://hdl.handle.net/2268/22385

Doucet J.-L., Daïnou K., Ligot G., Ouédraogo D.-Y., Bourland N., Ward S.-E., et al., 2016. Enrichment of Central African logged forests with high-value tree species: testing a new approach to regenerating degraded forests. International Journal of Biodiversity Science, Ecosystem Services and Management, 12 (1-2): 83-95. https://doi.org/10.1080/21513732.2016.1168868 
Doumenge C., Coppens G., Chevallier M.-H., Todou G., Niangadouma R., Fauvet N., Chevillotte H., 2010. Évaluation des niches climatiques de quatre espèces d'Entandrophragma (Meliaceae) d'Afrique occidentale et centrale. Implications évolutives et paléoclimatiques. In : Jeannoda V. H., Razafimandimbison S. G., De Block P. (éds). XIXe Congrès de l'AETFAT, 25-30 avril 2010, Antananarivo, Madagascar. Résumés. Scripta Botanica Belgica, $46: 153$.

Dupuy B., 1998. Bases pour une sylviculture en forêt dense tropicale humide africaine. Montpellier, France, Cirad-Forêt, 329 p. http://agritrop.cirad.fr/315216/

Durrieu de Madron L., Daumerie A., 2004. Diamètre de fructification de quelques essences en forêt naturelle centrafricaine. Bois et Forêts des Tropiques, 281 : 87-95. https://doi. org/10.19182/bft2004.281.a20230

Durrieu de Madron L., Forni E., 1997. Aménagement forestier dans l'est du Cameroun : Structure du peuplement et périodicité d'exploitation. Bois et Forêts des Tropiques, 254 : 39-50. https://doi.org/10.19182/bft1997.254.a19897

Durrieu de Madron L., Nasi R., Détienne P., 2000. Accroissements diamétriques de quelques essences en forêt dense africaine. Bois et Forêts des Tropiques, $263: 63-73$. https://doi. org/10.19182/bft2000.263.a20062

Eckebil P. P. T., Verheggen F., Doucet J.-L., Malaisse F., Daïnou K., Cerutti P. O., et al., 2017. Entandrophragma cylindricum (Sprague) Sprague (Meliaceae), une espèce ligneuse concurrentielle en Afrique centrale (synthèse bibliographique). Biotechnologie, Agronomie, Société et Environnement, 21 : 80-97. https://popups.uliege.be/1780-4507/index.php?id=13508

Fargeot C., Forni E., Nasi R., 2004. Réflexions sur l'aménagement des forêts de production dans le bassin du Congo. Bois et Forêts des Tropiques, 281 : 19-34. https://doi.org/10.19182/ bft2004.281.a20223

Fétéké F., Fayolle A., Daïnou K., Bourland N., Dié A., Lejeune P., et al., 2016. Variations saisonnières de la croissance diamétrique et des phénologies foliaire et reproductive de trois espèces ligneuses commerciales d'Afrique centrale. Bois et Forêts des Tropiques, 330 : 3-21. https://doi.org/10.19182/ bft2016.330.a31315

Fétéké F., Perin J., Fayolle A., Daïnou K., Bourland N., Kouadio Y.-L., et al., 2015. Modéliser la croissance de quatre essences pour améliorer la gestion forestière au Cameroun. Bois et Forêts des Tropiques, 325 : 5-20. https://doi.org/10.19182/ bft2015.325.a31269

Fischer E., Rembold K., Althof A., Obholzer J., Malombe I., Mwachala G., et al., 2010. Annotated checklist of the vascular plants of Kakamega Forest, Western Province, Kenya. Journal of East African Natural History, 99 (2): 129-226. https://doi. org/10.2982/028.099.0205

Geist H., Lambin E., 2002. Proximate causes and underlying driving forces of tropical deforestation. BioScience, 52 (2): 143-150. https://doi.org/10.1641/0006-3568(2002)052[0143:PCAUDF]2.0.CO;2

Gérard J., 1999. Comportement et caractéristiques technologiques des bois de forêt naturelle : évolution des méthodes d'étude en relation avec l'adéquation qualité-usages. In : Nasi R., Amsallem I., Drouineau S. (éds). La gestion des forêts denses africaines aujourd'hui. Actes du séminaire Forafri de Libreville, Gabon, 12-16 octobre 1998, Cirad-Forêt, Cifor, Forafri. Montpellier, France, Cirad-Forêt. http://agritrop.cirad.fr/392132/ Gérard J., Edi Kouassi A., Daigremont C., Détienne P., Fouquet D., Vernay M., 1998. Synthèse sur les caractéristiques technologiques de référence des principaux bois commerciaux africains. Montpellier, France, Cirad-Forêt, Série Forafri, 11, 185 p. https://agritrop.cirad.fr/315469/
Gérard J., Guibal D., Paradis S., Cerre J.-C., 2016. Atlas des bois tropicaux. Versailles, France, Éditions Quæ, coll. Guide pratique, $999 \mathrm{p}$.

Gillet J.-F., Ngalouo B., Missamba-Lola A. P., 2008. Rapport d'analyse - volet dynamique forestière. Projet CIB FFEM « Suivi du programme dynamique forestière - agroforesterie - inventaires faunes ». Ministère de l'Économie forestière, République du Congo.

Gillet P., Vermeulen C., Feintrenie L., Dessard H., Gracia M., 2016. Quelles sont les causes de la déforestation dans le bassin du Congo ? Synthèse bibliographique et études de cas. Biotechnologie, Agronomie, Société et Environnement, 20 (2) : 183-194.

Guibal D., Langbour P., Gérard J., 2015. Propriétés physiques et mécaniques des bois. In : Mille G., Louppe D. (éds). Mémento du forestier tropical. Versailles, France, Éditions Quæ, 873-884. Hall J. S., 2008. Seed and seedling survival of African mahogany (Entandrophragma spp.) in the Central African Republic: Implications for forest management. Forest Ecology and Management, 255: 292-299. https://doi.org/10.1016/j.foreco.2007.09.050 IAWA (International Association of Wood Anatomists) Committee, 1989. List of microscopic features for hardwood identification. IAWA Bulletin, new series (4th printing, 2007), 10: 219-332.

ITTO (International Tropical Timber Organization), 2017. Tropical Timber Market (TTM) Report. ITTO Market Information Service (MIS), volume 21, number 23, 1st-15th December 2017.

Jagoret P., Kwesseu J., Messie C. A., Michel I., Malézieux E., 2014. Valeurs d'usage des ligneux utilisés en agroforesterie : les cacaoyères du Centre-Cameroun. Bois et Forêts des Tropiques, 321: 45-54. https://doi.org/10.19182/bft2014.321.a31217

Karsenty A., 2004. Enjeux des réformes récentes de la fiscalité forestière dans le bassin du Congo. Bois et Forêts des Tropiques, 281 : 51-60. https://doi.org/10.19182/bft2004.281.a20227

Karsenty A., Ferron C., 2017. Recent evolutions of forest concessions status and dynamics in Central Africa. International Forestry Review, 19: 10-26. https://doi. org/10.1505/146554817822295957

Karsenty A., Ongolo S., 2012. Les terres agricoles et les forêts dans la mondialisation : de la tentation de l'accaparement à la diversification des modèles ? In : Agriculture et alimentation : des champs géopolitiques de confrontation au XXI ${ }^{\text {e }}$ siècle. Cahier Demeter, 13 : 99-108. http://agritrop.cirad.fr/563526/ Karsenty A., Vermeulen C., 2016. Vers des Concessions 2.0 - Articuler gestion inclusive et exclusive dans les forêts de production en Afrique centrale. In : Buttoud G., Nguinguiri J. C., Aubert S., Bakouma J., Karsenty A., Kouplevatskaya-Buttoud I., Lescuyer G. (éds). La gestion inclusive des forêts d'Afrique centrale : de la participation au partage des pouvoirs. Libreville, Gabon, FAO, Cifor, 205-223. http://hdl.handle.net/2268/198501

Kasongo Yakusu E., Monthe F. S., Bourland N., Hardy O. J., Louppe D., Bola Mbele Lokanda F., et al., 2018. Le genre Entandrophragma (Meliaceae) : taxonomie et écologie d'arbres africains d'intérêt économique (synthèse bibliographique). Biotechnologie, Agronomie, Société et Environnement, 22 (2). https:// popups.uliege.be:443/1780-4507/index.php?id=16353.

Kémeuzé V. A., 2008. Entandrophragma cylindricum (Sprague) Sprague. In : Louppe D., Oteng-Amoako A. A., Brink M. (éds). Ressources végétales de l'Afrique tropicale 7 (1). Bois d'œuvre 1. Traduction de : Plant Resources of Tropical Africa 7 (1). Timbers 1. 2008. Wageningen, Pays-Bas, Fondation PROTA, 268-273. https://www.prota4u.org/database/Entandrophragmacylindricum (consulté le 17/06/2016). http://edepot.wur.nl/417632

Lebacq L., Istas J. R., 1950. Les bois des Méliacées du Congo Belge. Volume 2. Tervuren, Belgique, Annales du Musée du Congo Belge, $127 \mathrm{p}$. 
Lemmens R. H. M. J., 2008. Entandrophragma excelsum (Dawe \& Sprague) Sprague. In : Louppe D., Oteng-Amoako A. A., Brink $M$. (éds). Ressources végétales de l'Afrique tropicale 7 (1). Bois d'œuvre 1. Traduction de : Plant Resources of Tropical Africa 7 (1). Timbers 1. 2008. Wageningen, Pays-Bas, Fondation PROTA, 273-280. http://edepot.wur.nl/417632

Lemmens R. H. M. J., Omino E. A., Bosch C. H., et al., 2010. Bois d'œuvre de l'Afrique tropicale. Conclusions et recommandations basées sur PROTA 7 (1) : Bois d'oeuvre 1. Traduction de : Timbers of Tropical Africa. Conclusions and recommendations based on PROTA 7 (1): Timbers 1. 2009. Nairobi, Kenya, Fondation PROTA, $92 \mathrm{p}$.

Leroy M., Vendé J., Aubert P. M., Espinosa L., Leménager T., 2011. Concept et dispositifs de gestion durable des forêts tropicales : une analyse critique de la prise en charge des enjeux environnementaux. Actes du colloque SIFFE, Yaoundé, Cameroun. http:// www.sifee.org/static/uploaded/Files/ressources/actes-descolloques/yaounde/pleniere-2-2/2 LEROY DERROIRE TXT.pdf (consulté le 05/12/2017).

Lescuyer G., Cerutti P. O., Essiane E., Ebaa R., Nasi R., 2012. Évaluation du secteur du sciage artisanal dans le bassin du Congo. In : De Wasseige C., de Marcken P., Bayol N., Hiol Hiol F., Mayaux P., Desclée B., Nasi R., et al. (éds). Les forêts du bassin du Congo - État des forêts 2010. Luxembourg, Office des publications de l'Union européenne.

Lisingo J., Lokinda F., Wetsi J.-L., Ntahobavuka H., 2012. Exploitation artisanale du bois et des chenilles comestibles par les habitants de la ville de Kisangani et ses environs. In : Benneker C., Assumani D.-M., Maindo A., Bola F., Kimbuani G., Lescuyer G., et al. (éds). Le bois à l'ordre du jour. Exploitation artisanale de bois d'œuvre en RD Congo : Secteur porteur d'espoir pour le développement des petites et moyennes entreprises. Wageningen, Pays-Bas, Tropenbos International, 248-262.

Louppe D., 2015. Anatomie des bois. In : Mille G., Louppe D. (éds). Mémento du forestier tropical. Versailles, France, Éditions Quæ, 859-867.

Louppe D., Oteng-Amoako A. A., Brink M. (éds), 2008. Ressources végétales de l'Afrique tropicale 7 (1). Bois d'œuvre 1. Traduction de : Plant Resources of Tropical Africa 7 (1). Timbers 1. 2008. Wageningen, Pays-Bas, Fondation PROTA, 785 p.

Louppe D., Ouatara N., 2013. Étude sur l'exploitation forestière et les contraintes d'une gestion des forêts dans le domaine rural en Côte d'Ivoire. Abidjan, Côte d'Ivoire, Deutsche Gesellschaft für Internationale Zusammenarbeit (GIZ), 216 p.

Lourmas M., Kjellberg F., Dessard H., Joly H. I., Chevallier M. H., 2007. Reduced density due to logging and its consequences on mating system and pollen flow in the African mahogany Entandrophragma cylindricum. Heredity, 99: 151-160. https://www. nature.com/articles/6800976

Marien J.-N., Gourlet-Fleury S., 2014. Les plantations forestières en Afrique centrale : des sylvicultures nouvelles pour répondre aux nouveaux besoins des sociétés. In : De Wasseige C., Flynn J., Louppe D., Hiol Hiol F., Mayaux Ph. (éds). Les forêts du bassin du Congo - État des forêts 2013. Neufchâteau, Belgique, Weyrich, 197-212. http://www.observatoire-comifac.net/docs/ edf2013/FR/EDF2013 FR chap8.pdf

Marien J.-N., Mallet B., 2004. Nouvelles perspectives pour les plantations forestières en Afrique centrale. Bois et Forêts des Tropiques, 282 : 67-79. https://doi.org/10.19182/ bft2004.282.a20221

Mate J.-P., Lusuna M., Nshimba H., Ndjele L., 2013. Les essences forestières à charbon de bois aux environs de Kisangani. In : Marien J.-N., Dubiez E., Louppe D., Larzillière A. (éds). Quand la ville mange la forêt. Les défis du bois-énergie en Afrique centrale. Versailles, France, Éditions Quæ, 159-166.
Meunier Q., Moumbogou C., Doucet J.-L., 2015. Les arbres utiles du Gabon. Gembloux, Belgique, Presses agronomiques de Gembloux, 340 p. http://hdl.handle.net/2268/183815

Monthe F. K., Duminil J., Kasongo Yakusu E., Beeckman H., Bourland N., et al., 2018. The African timber tree Entandrophragma congoense (Pierre ex De Wild.) A.Chev. is morphologically and genetically distinct from Entandrophragma angolense (Welw.) C.DC. Tree Genetics \& Genomes, 14: 66. https://doi. org/10.1007/s11295-018-1277-6

Monthe F. K., Hardy O. J., Doucet J.-L., Loo J., Duminil J., 2017. Extensive seed and pollen dispersal and assortative mating in the rain forest tree Entandrophragma cylindricum (Meliaceae) inferred from indirect and direct analyses. Molecular Ecology, 26: 5279-5291. https://doi.org/10.1111/mec.14241

Mujuni D. B., 2008. Entandrophragma utile (Dawe \& Sprague) Sprague. In : Louppe D., Oteng-Amoako A. A., Brink M. (éds). Ressources végétales de l'Afrique tropicale 7 (1). Bois d'œuvre 1. Traduction de : Plant Resources of Tropical Africa 7 (1). Timbers 1. 2008. Wageningen, Pays-Bas, Fondation PROTA. https:// www.prota4u.org/database/Entandrophragmautile (consulté le 17/06/2016)

Nanson A., 2004. Génétique et amélioration des arbres forestiers. Gembloux, Belgique, Presses agronomiques de Gembloux, $712 \mathrm{p}$.

Nyunaï N., 2008. Entandrophragma candollei Harms. In : Louppe D., Oteng-Amoako A. A., Brink M. (éds). Ressources végétales de l'Afrique tropicale 7 (1). Bois d'œuvre 1. Traduction de : Plant Resources of Tropical Africa 7 (1). Timbers 1. 2008. Wageningen, Pays-Bas, Fondation PROTA. https://www. prota4u.org/database/Entandrophragmacandollei (consulté le 17/06/2016)

Owona Ndongo P.-A., 2006. Évaluation de la potentialité des plantations forestières au Centre-Sud Cameroun : Résultats des mesures effectuées dans l'arboretum de Mbalmayo et des enquêtes menées en périphérie de sa réserve. Mémoire de stage, Cirad, France.

Onifade A. K., 2006. Effect of essential oils of some Meliaceous plants on aflatoxin production and growth of Aspergillus parasiticus. Journal of Food Technology, 4: 322-324. http://medwelljournals.com/abstract/?doi=jftech.2006.322.324

Owona Ndongo P.-A., Peltier R., Linjouom I., Louppe D., Smektala G., Beligné V., et al., 2009. Plantations de bois d'œuvre en zone équatoriale africaine : cas de l'arboretum de l'Enef de Mbalmayo au sud du Cameroun. Bois et Forêts des Tropiques, 299 : 37-48. https://doi.org/10.19182/bft2009.299.a20421

Palla F., Louppe D., Forni E., 2002. Sapelli. Fiche technique, écologique et sylvicole. Montpellier, France, Cirad-Forêt.

Petrucci Y., Tandeau de Marsac G., Morel P. J., 1995. Évolution du peuplement adulte et de la régénération acquise après interventions sylvicoles. Dispositif de recherche en forêt dense de Boukoko-La Lolé. Appui à la recherche forestière FAC/ARF. Bangui, République centrafricaine, Ministère des Eaux, Forêts, Chasse et Pêche, $55 \mathrm{p}$.

Plumptre A. J., 1995. The importance of "seed trees" for the natural regeneration of selectively logged tropical forest. Commonwealth Forestry Review, 74: 253-258.

Poorter L., Bongers F., Kouamé F. Y. N., Hawthorne W.-D., 2014. Biodiversity of West African Forests: An Ecological Atlas of Woody Plant Species. Wallingford, United Kingdom, CABI Publishing, 521 p. https://www.jstor.org/stable/42608376

Sépulchre F., Daïnou K., Doucet J.-L., 2008. Étude de la vulnérabilité de 18 essences ligneuses commerciales d'Afrique centrale reprises sur la liste rouge UICN. Gembloux, Belgique, Université des Sciences agronomiques de Gembloux. https:// www.atibt.org/wp-content/uploads/2017/06/Etude_vulnerabilite Gembloux 2008.pdf 
Staner P., Gilbert G., 1958. Meliaceae. In : Robyns W., Staner P., Demaret F., Germain R., Gilbert G., et al. (éds). Flore du Congo Belge et du Rwanda-Urundi. Spermatophytes. Volume 7. Bruxelles, Belgique, Institut national pour l'étude agronomique du Congo belge (INEAC), 147-213.

Tailfer Y., 1989. La forêt dense d'Afrique centrale. Identification pratique des principaux arbres. Tome I. Approche forestière et morphologique. Québec, Canada, Agence de coopération culturelle et technique, Wageningen, Pays-Bas, Centre technique de coopération agricole et rurale.

Tchinda A. T., 2008. Entandrophragma angolense (Welw.) C.DC. In : Louppe D., Oteng-Amoako A. A., Brink M. (éds). Ressources végétales de l'Afrique tropicale 7 (1). Bois d'œuvre 1. Traduction de : Plant Resources of Tropical Africa 7 (1). Timbers 1. 2008. Wageningen, Pays-Bas, Fondation PROTA. https://www.prota4u.org/database/Entandrophragmaangolense (consulté le 17/06/2016).

Temgoua L., Njouka R., Peltier R., 2011. Plantations ingénieuses de bois d'œuvre par les paysans de l'Ouest-Cameroun. Bois et Forêts des Tropiques, 309 : 63-76. https://doi.org/10.19182/ bft2011.309.a20467

Tiayon F., Molnar A., 2012. Perspectives comparatives de l'exploitation artisanale du bois en RD Congo : évolution des politiques et des pratiques. In : Benneker C., Assumani D.-M., Maindo A., Bola F., Kimbuani G., Lescuyer G., et al. (éds). Le bois à l'ordre du jour. Exploitation artisanale de bois d'œuvre en RD Congo : secteur porteur d'espoir pour le développement des petites et moyennes entreprises. Wageningen, Pays-Bas, Tropenbos International, 133-135.

Tieguhong J. C., Snook L., Taedoumg H., Maukonen P., Tchatat M., Loo J., et al., 2017. Beyond timber: balancing demands for tree resources between concessionaires and villagers. International Forestry Review, 19 (S2): 14. https://www.bioversityinternational.org/index.php?id=244\&tx news pi $1 \% 5$ Bnews $\% 5 \mathrm{D}=9554$

Tshimpanga P., Lescuyer G., Vleminckx J., Adebu B., Lokombe D., 2016. Utilité d'une typologie des exploitants artisanaux de bois pour contribuer à la formulation d'une politique publique en province Orientale (RD Congo). Biotechnologie, Agronomie, Société et Environnement, 20 : 468-481. https://popups. uliege.be/1780-4507/index.php?id=13242

UICN (Union internationale pour la conservation de la nature), 2012. Catégories et Critères de la Liste rouge de l'UICN : Version 3.1. Deuxième édition. Gland, Suisse, Cambridge, RoyaumeUni, UICN, 32 p. Originalement publié en tant que IUCN Red List Categories and Criteria : Version 3.1. Second edition.

Van der Sleen P., Groenendijk P., Zuidema P. A., 2015. Tree-ring $\delta^{18} \mathrm{O}$ in African mahogany (Entandrophragma utile) records regional precipitation and can be used for climate reconstructions. Global and Planetary Change, 127: 58-66. https://doi. org/10.1016/i.gloplacha.2015.01.014

Vermeulen C., Schippers C., Ntoune M. F. D., Bracke C., 2009. Enjeux méthodologiques autour des produits forestiers non ligneux dans le cadre de la certification en Afrique centrale. Bois et Forêts des Tropiques, $300: 69-78$. https://doi.org/10.19182/ bft2009.300.a20416

Wheeler E., Baas P., Gason P., 1989. IAWA List of Microcopie Features for Hardwood Identification. IAWA Journal, 10 (3): 219 332. https://doi.org/10.1002/fedr.19901011106

White F., 1986. La végétation de l'Afrique. Mémoire accompagnant la carte de végétation de l'Afrique. Paris, France, Orstom et Unesco. http://horizon.documentation.ird.fr/exl-doc/ pleins textes/divers11-06/24837.pdf

White L., Gasson P., 2008. Mahogany. Kew, United Kingdom, Kew Publishing, 99 p.
Yalibanda Y., 1999. Phénologie en forêt dense de Ngotto (Rca). Bilan de trois années d'observation. In : Nasi R., Amsallem I., Drouineau S. (éds). La gestion des forêts denses africaines aujourd'hui. Actes du séminaire Forafri de Libreville (Gabon), 12-16 octobre 1998. Montpellier, France, Cirad-Forêt, cédérom, 24 p. http://agritrop.cirad.fr/392581/

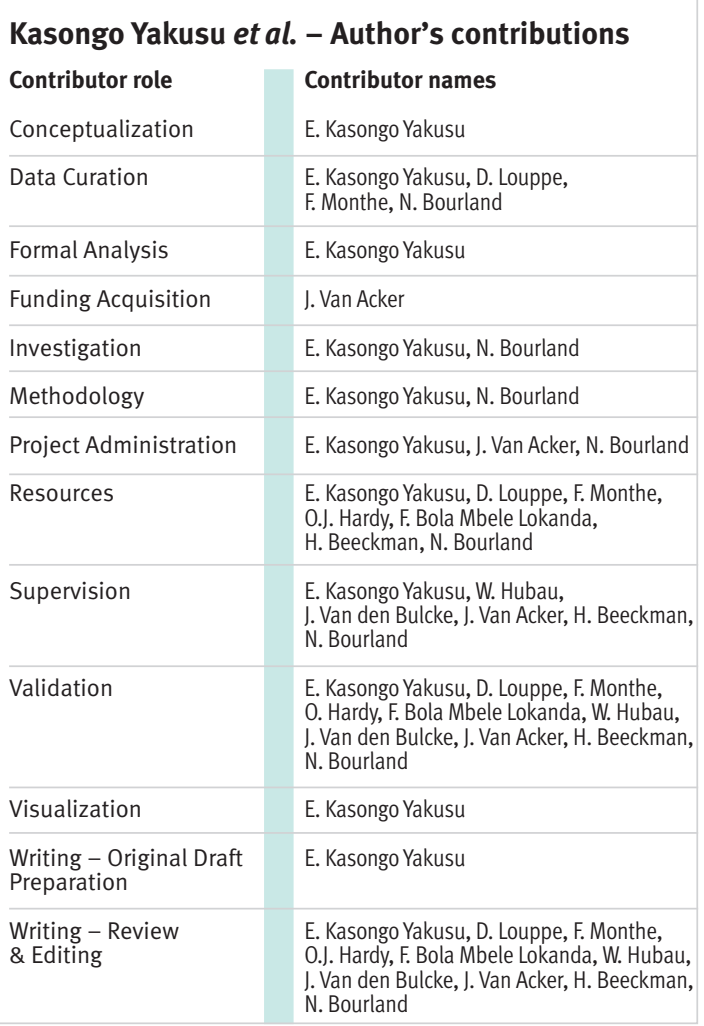

Bois et Forêts des Tropiques - Revue scientifique du Cirad (c) Bois et Forêts des Tropiques (C) Cirad
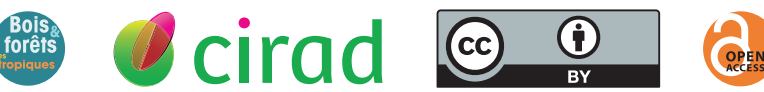

Cirad - Campus international de Baillarguet, 34398 Montpellier Cedex 5, France Contact : bft@cirad.fr - ISSN : L-0006-579X 